\title{
2-6 Yaş Arası Çocuğu Olan Annelerin Öfke Düzeyi ile Çocuk Yetiştirme Tutumu Arasındaki İlişkinin İncelenmesi*
}

Investigation of the relationship Between Child Rearing Attitude of Mothers with Children Between the Ages of 2-6 and Their Anger Level

\author{
Öznur Doğan** - Cihad Demirli***
}

\begin{abstract}
Anger, just like happiness and sadness, is among the verbal or non-verbal expression styles exhibited against the individual who causes that emotion. Anger can lead to many problems when it is experienced more than necessary and manifests itself with aggressive attitudes. Anger is a feeling that manifests itself in different ways in each person. These are expressed in the form of inward expression, expression and anger control. Anger is a very beneficial feeling if it is in appropriate dosage and is shortterm. However, when anger is constant and violent, it turns into a devastating feeling. Therefore, it is extremely important to know the factors that cause anger and how anger is expressed. Factors affecting how anger is expressed include age, gender, education level, marital status, and culture. Anger within the family has negative consequences for all family members. The objective of this study is to investigate the relationship between the anger level of mothers who have children between the ages of 2-6 and their attitude towards child rearing. In accordance with this purpose, a questionnaire was conducted with 112 participants residing in Istanbul. As a result of the research, a positive relationship was observed between the anger symptoms level and the overprotective attitude and depression levels; the level of not being taken seriously and the levels of injustice and criticism; and the level of injustice and the levels of criticism of the mothers forming the research group.
\end{abstract}

Structured Abstract: The "family" institution, which affects the individual in many respects and provides the first interactions of the child, has a great importance in the "good" upbringing of young people and children, which make up the majority of the population, from the prenatal period. Family is the first step in

${ }^{*}$ Bu çalışma İstanbul Ticaret Üniversitesi Sosyal Bilimler Enstitüsü Aile Danışmanlığı ve Eğitimi alanında yüksek lisans tezinden üretilmiş bir çalışmadır. 2019 yılı şubat ayında İstanbul Ticaret Üniversitesi çalışılacak konuyu inceleyip kullanılacaklar ölçekleri değerlendirdikten sonra etik kurul onayına gerek olmadığına karar vermiştir. Bu kararın ardından 2019 yılı şubat ayında araştırma çalışması için gerekli veriler toplanmaya başlanmıştır.

** Yüksek Lisans Öğrencisi, İstanbul Ticaret Üniversitesi, Sosyal Bilimler Enstitüsü, Aile Danışmanlığı ve Eğitimi Anabilim Dalı

Graduate student, Istanbul Commerce University, Enstitu of Social Sciences, Department of Family Counseling and Education

ORCID 0000-0001-7255-510X

oznurgdogan@gmail.com

*** Prof. Dr., İstanbul Ticaret Üniversitesi, İnsan ve Toplum Bilimleri Fakültesi, Eğitim Bilimleri Bölümü

Prof. Dr., İstanbul Commerce University, Faculty of Humanities and Social Sciences, Department of Educational

Sciences

ORCID 0000-0002-0911-9003

cdemirli@ticaret.edu.tr

Cite as/ Atıf: Doğan, Ö. \& Demirli, C. (2020). 2-6 yaş arası çocuğu olan annelerin öfke düzeyi ile çocuk yetiştirme tutumu arasındaki ilişkinin incelenmesi. Turkish Studies, 15(5), 2309-2331. https://dx.doi.org/10.7827/TurkishStudies.44405

Received/Geliş: 22 June/Haziran 2020

Accepted/Kabul: 25 August/Ağustos 2020

Copyright $($ ) MDE, Turkey

Checked by plagiarism software

Published/Yayın: 31 August/Ağustos 2020

CC BY-NC 4.0 
the socialization of the child. The quality of the relationship between the family and the child and the child's positive or negative perception of the relationship in question greatly affect the child's personality development and social relations. Therefore, it is thought that it affects the later stages of the individual's life to a large extent (Yaşar, 2009, p. 19). From the moment parents start thinking about having children, they also begin to show their motherhood and fatherhood attitudes and skills. Particular attention, compassion, understanding, tolerance, help, support and encouragement behaviors are exhibited by parents. Thus, parents become strong role models for their children about their feelings, attitudes and behaviors in future periods.

In addition to that, it is stated that anger and anger reflection behaviors, which are among the emotions and behaviors shaped in the family environment, are an important research subject. It is known that anger has an extremely important effect on the social relations of the child. Therefore, how often the child experiences anger and how he or she reflects it is generally shaped in the family environment (Aydin \& Öztütüncü, 2001, p. 79). The first bond with the parent can affect the individual's social relationships as stated. In addition, according to the majority of researchers, the bond in question affects the individual's relationship with others and their self-perception (Safran, 1990, p. 89). The nature of the bond that the individual establishes with the attachment figure in the early period affects the relationships that the individual establishes in adulthood, his or her ideas about "who" and the concept of self (Çelik, 2006, p. 42). In addition, it is stated that the bond established with the parents will have a great impact on the beliefs about how the parents' attitude will be against child's behaviors. The quality of the parents' bond with the child is thought to create a perception that suggests that the child is accepted or rejected by the parent.

It is thought that the bond that parents establish with the child will affect the child's perception of anger, as well as their perception of how parents will behave in the face of some behaviors exhibited by the child. It is also thought that the child's level of anger experience will greatly affect the parents' behavior towards the child. In this study, it was aimed to investigate the effect of anger level of mothers who have children between the ages of 2-6 on their parenting attitude. The sub-objectives determined in line with the determined purpose can be listed as the examination of the effect of the mothers with children between the ages of 2-6 not being taken seriously, being subjected to injustice and criticism on their attitudes towards child rearing. The sample of the study consists of 112 participants who are randomly selected from the universe and live in Istanbul. The Anger Symptoms Scale, Anger Causes Scale, Parental Attitude Scale and Beck Depression Scale, which are used as data collection tools in the research, are likert-type expressions consisting of 122 expressions in total. Descriptive statistics are specified as frequency (f), percentage (\%), mean $(\overline{\mathrm{X}})$, standard deviation (SD), minimum and maximum values in the analysis. Whether or not the scales fit the normal distribution assumption is determined by looking at the skewness and kurtosis coefficients. In addition, while the independent sample $t$ test was used for comparing two groups of normally distributed variables, one-way ANOVA test was used for comparisons of three or more groups. The relationships between the variables of the research, which were created in line with the hypotheses of the research, were examined by Pearson Correlation test. In addition, according to the findings obtained from the correlation analysis; The effect of mothers' anger and depression levels on child rearing attitude was analyzed by linear regression analysis and multiple linear regression analysis. All the obtained results were evaluated at the level of statistical significance $\mathrm{p}<0.05$. As a result of the analyzes, it was evaluated that the anger symptoms levels of the mothers forming the research group negatively affect their authoritarian attitude levels, mothers' anger symptoms and not being taken seriously contributed significantly to overprotective attitudes, while the levels of being subjected to injustice did not contribute significantly.

Roopnarine, Jin and Krishnakumar (2014) investigated Guyanese mothers, their childcare routines and their effects on children. As a result of their study, they found that there was a positive correlation between the physical contacts that reflected anger on the children and their protective attitudes. With the research which has its results shared here, it is revealed that there is a positive relationship between the level of anger symptoms and protective attitude of the mothers. In this respect, the researches support each other. Although only the level of anger symptom was taken into consideration with the research conducted, the values represented by the result attitude were similar. It is noteworthy that the two studies yielded similar results in different geographies.

Ross and Wiiligen (1996) conducted a research which dealt with the relationship between gender, parenting and anger.

Turkish Studies, 15(5) 
In their study for this purpose, they examined single, married, single parent female and male individuals in families, belonging to various socioeconomic groups. As a result of their research, they found that the angriest group was women who were parents.

Malete (2007) examined the antisocial behaviors displayed by adolescents and their family connections. As a result of the study conducted with this purpose on 1,478 young people between the ages of 12 and 20, significant links were found between the violent and antisocial behaviors of adolescents and the low control level of families and inadequate parent-child relationships. When the research results of Malete (2007) considered together with the increasing anger symptom level and the decreasing authority attitude level revealed as a result of this research are examined, it can be concluded that the increase in anger symptom level has negative effects on adolescents' social attitudes. Although the adequacy of the connection requires further research, the negative effects of anger symptom level increase are again revealed by this study.

Çuhadaroğlu-Çetin et al. (2004) examined adolescents' mental status and family structures together in their report. It was observed in the report that the parents of the children who do not have problem solving, communication, social roles, emotional reaction and sufficient social skill levels also do not have sufficient levels of these skills. This report reveal the relationship between the level of anger manifestation and the level of authority attitude and the level of not being taken seriously. If this result is associated with Çuhadaroğlu-Çetin et al.'s (2004) results, it can be said thatthe high anger symptom level that the raised child is exposed will cause low social skills that he or she will exhibit when he or is adolescent. New research proposals can be introduced for an in-depth study of this association between the two studies.

Morris et. al.'s (2011) study suggests an emotional control strategy in child-mother relationship and in accordance with this application, observed and reported emotional states have been reported in accordance with that. When the proposed strategy is applied, it was found that there is a positive and opposite link on the sadness cases observed and declared on children. If the research of which the results are shared here and Morris et. al.'s (2011) research is evaluated together, it can be thought that the level of anger symptoms has a linear relationship on the level of sadness observed on children. If the fact that the observed demographic groups could have played a role is taken into account, in order to explain the relationship between research, new research proposals can be brought onto the table.

Kabasakal (2013) examined the functionality of mother education programs in a study. Functional levels of families with children who exhibit violent behavior, as found from the research results were not found to be healthy in terms of seven basic functions. These functions are problem solving, communication, basic roles, emotional response ability, required anxiety level, behavior control and general functions. Given the relationship between Kabasakal's research (2013) and the level of taking seriousness, providing authority and anger level symptom level shared here, it can be said that the results of the researches support each other and there is a connection between the level of being taken seriously and providing authority and the effect on children's functional skills.

Keywords: Anger Level, Child Rearing, Attitude, Mother

Öz: Mutluluk ve üzüntü gibi öfke de o duyguyu yaşatan bireye karşı sergilenen sözel ya da sözel olmayan dışa vurum tarzları arasında yer almaktadır. Öfke, gereğinden fazla yaşandığında ve kendini saldırgan tavırlarla gösterdiğinde pek çok problemin ortaya çıkmasına yol açabilmektedir. Öfke, insanların her birinde farklı şekillerde kendini gösteren bir duygudur. Bunlar içe vurum, dışa vurum ve öfke kontrolü biçiminde ifade edilmektedir. Öfke, dozunda ve kısa süreli ve dozunda olursa son derece faydalı bir duygudur. Ancak öfke sürekli ve şiddetli olduğunda yıkıcı bir duyguya dönüşmektedir. Dolayısıyla öfkeye yol açan faktörlerin bilinmesi ve öfkenin ifade edilme şekli son derece önemlidir. Öfkenin ifade edilme şeklini etkileyen faktörler arasında yaş, cinsiyet, eğitim düzeyi, medeni durum ve kültür yer almaktadır. Aile içinde ortaya çıkan öfke ise aile fertlerinin tamamı üzerinde negatif sonuçlar doğurmaktadır. Bu çalışmanın amacı 2-6 yaş arası çocuğu olan annelerin öfke düzeyi ile çocuk yetiştirme tutumu arasındaki ilişkinin incelenmesidir. Bu amaç doğrultusunda İstanbul'da ikamet eden 112 katılımcı ile anket uygulaması yapılmıştır. Yapılan araştırmada veri toplama aracı olarak Öfke Belirtileri Ölçeği, Ebeveyn Tutum Ölçeği ve Beck Depresyon Ölçeği toplamda 122 ifadeden oluşan likert tipi anket formu kullanılmıştır. Araştırma sonucunda araştırma grubunu oluşturan annelerin, öfke belirtileri düzeyi ile aşırı koruyucu tutum ve depresyon düzeyi arasında; ciddiye 
alınmama düzeyi ile haksızlığa uğrama ve eleştirilme düzeyleri arasında; haksızlığa uğrama düzeyi ile eleştirilme düzeyleri arasında, eleştirilme düzeyi ile izin verici tutum düzeyleri arasında pozitif yönlü ve istatistiksel olarak anlamlı bir ilişki tespit edilmiştir.

Anahtar Kelimeler: Aile Danışmanlığı, Öfke Düzeyi, Çocuk Yetiştirme Tutumu, Anne

\section{Giriş}

Çocukların gelişim süreci içerisinde önemli zaman dilimlerinden birisi de erken çocukluk dönemidir. Söz konusu dönemde çocukların gelişimine etki eden pek çok faktör bulunmaktadır. Çevre ise bu faktörlerin başında gelmektedir. Çocuğun yaşamının ilk dönemlerinde çevresinin yalnızca aile bireylerinin oluşturduğu kısıtlı bir gruptan meydana geldiği görülmektedir. Çocuğun gelişiminin normal bir seyir gösterebilmesi için yakın çevresinde yer alan aile bireylerinin pozitif bir tutum sergilemeleri gerektiği, çocuğa karşı sevgi duygusunu hissettirebilmeleri gerektiği söylenebilir (Çıkrıkçı,1999). Çocuğun sağlıklı gelişiminde ebeveynlerin gösterecekleri sevgi ve ilgi son derece büyük öneme sahiptir. Bireylerin kişilik gelişiminin temelleri çocukluk döneminde atılmaktadır. Bu bağlamda ebeveynlerin çocuklar için önemli birer rol model oldukları söylenebilir. Çocuklar çevrelerinde yer alan ve rol model olarak gördükleri kişilerle özdeşim kurmakta ve kendi benliklerini şekillendirmektedirler. Ebeveynlerin çocuklara karşı sergileyecekleri davranışlarda, ebeveynlerin yaşı, eğitim seviyeleri ve ailedeki çocuk sayısı gibi pek çok farklı faktör etkili olmaktadır (Balat, 2010). Ebeveyn ve çocuk arasında kurulan ilişkiyi esas alan teorilerin büyük bir bölümü, ebeveynlerin çocukların yaşamlarının ilk yıllarında onlara nasıl etki ettikleri üzerinde durmaktadır. Yapılan araştırmalar, erken dönemdeki aile tecrübelerinin çocukluk ve ebeveyn özellikleri bakımından önemli bir temel oluşturduğunu ortaya koymaktadır. Gelişim ile ilgili teorilerde, ebeveynlerin tutumları göz önünde bulundurulmakta ve ebeveynlerin çocuklar üzerindeki rolleri ortaya koyulmaktadır (Maccoby, 2002). Ebeveynler ile çocuklar arasındaki ilişkinin olumlu bir seyir göstermesi, çocukların sosyalleşmelerinde ve öz kontrollerinin gelişmesinde büyük bir paya sahiptir (Senemoğlu, 2009).

Nüfusun büyük bir kısmını oluşturan gençlerin ve çocukların "iyi” yetiştirilmesinde, doğum öncesi dönemden itibaren yaşamın büyük bir kısmında, kişiyi pek çok açıdan etkileyen ve çocuğun ilk etkileşimlerinin yaşandığ 1 "aile" kurumu büyük bir öneme sahiptir. Çocuğun toplumsallaşmasında ilk basamağı aile oluşturmaktadır. Aile ve çocuk arasında kurulan ilişkinin niteliği ve çocuğun söz konusu ilişkiyi pozitif ya da negatif algılayışı çocuğun kişilik gelişimini ve sosyal ilişkilerini büyük ölçüde etkilemektedir. Dolayısıyla bireyin yaşamının daha sonraki aşamalarını da büyük oranda etkilediği düşünülmektedir (Yaşar, 2009: 19). Ebeveynler, çocuk sahibi olmayı düşünmeye başladıkları andan itibaren annelik babalık tutum ve becerilerini de sergilemeye başlarlar. Ebeveynler tarafından özellikle ilgi, şefkat, anlayış, hoşgörü, yardım, destek ve cesaretlendirme davranışları sergilenmektedir. Böylece ebeveynler çocuklarına onların gelecek dönmelerdeki duyguları, tutumları ve davranışları için güçlü rol modelleri olurlar. Öte yandan aile ortamında şekillenen duygu ve davranışlar arasında yer alan öfke ve öfkeyi yansıtma davranışlarının önem taşıyan bir araştırma konusu olduğu belirtilmektedir. Literatürde öfke; tehdit algılama, eleştirilme, haksızlığa maruz kalma, engellenme gibi olumsuz koşullara bağlı olarak meydana gelen bir duygu şeklinde tanımlanmaktadır (Bilge \& Sayın, 1994: 111). Bu sayılan durumlar arasında engellenme halinin öfke duygusuna sebebiyet veren en temel unsur olduğu noktasında birçok yazar fikir birliği içerisindedir. Bununla birlikte öfke duygusu, ne zaman ortaya çıktığına ilişkin bir sınıflandırmaya da tabi tutulmaktadır (Baltaş \& Baltaş, 2008).

Ebeveynlerin çocuk yetiştirme davranışları farklı toplumlarda değişkenlik göstermektedir. $\mathrm{Bu}$ değişkenlik içerisinde bulunulan toplumun benimsediği değerler ve demografik özelliklere göre şekillenmektedir. Çocuk yetiştirme davranışlarının çocuklarda bırakacağı negatif etkinin minimum seviyede tutulabilmesi, çocukların gelişimlerinin sağlıklı bir şekilde devam ettirilebilmesi bakımından önem taşımaktadır. Ebeveynlerin çocuklarıyla kurdukları ilişki doğum ile beraber 
başlamakta özellikle yaşamlarının ilk dönemlerinde çocukları etkilemektedir (Gülay ve Önder, 2011; Parke ve ark., 2004). Bu etki nedeniyle özellikle okul öncesi dönemde ebeveynlerin çocuk yetiştirme tutumlarının değerlendirilmesi önem taşımaktadır. Literatürde yer alan çalışmalar ele alındığında, Türkiye'de 2-6 yaş aralığındaki çocukların ebeveyn tutumlarını ele alan herhangi bir çalışmaya rastlanılmamıştır. Dolayısıyla bu konuda gerçekleştirilecek bir çalışmanın literatüre pozitif bir katkı sunacağı düşünülmektedir.

Sydeman, Reheiser, Spielberger (1995: 207) öfke duygusunu sürekli öfke ve durumluk öfke olmak üzere ikiye ayırarak incelemiştir. Durumluk öfke kavramı, öfkenin ortaya çıkmasına yol açan olgunun meydana geldiği anda öfkeyi doğurmakla birlikte öfke hissinin şiddetinin zamanla ve kişinin çevresindeki uyaranlara bağli olarak değişkenlik gösterdiği öznel bir öfke hali şeklinde tanımlamaktadır. Sürekli öfke kavramı ise, kişinin öfkeli olma halinin süreklilik arz etmeye meyilli olması şeklinde tanımlanabilir (Özer, 1997: 82). Öfke duygusunu ortaya çıkaran unsurlar incelendiğinde yegane bir cevaba ulaşmak mümkün değildir. Öğretiye göre engellenme, bu unsurlar arasında en büyük rol oynayandır. Kişiler hayatlarının her döneminde, öfke hissine yol açan kendine has engellemelerle karşılaşmaktadır. Bebeklik döneminde bir eylemin engellenmesi gibi küçük kısıtlamalar öfkeye yol açarken, çocukluk döneminde isteklerin reddedilmesi, terbiye ve eğitim verilmesi, başarısızlık yaşamak ya da ebeveyn ilgisini yitirmek gibi unsurlar öfkeye yol açabilir (Yavuzer, 2014: 42-43). Ergenlik döneminde kişiler esasında iki temel arzu arasında kalmaktadır, bu kişiler hem yetişkinlerin desteğine gereksinim duymakta ve güvensizlik yaşamaktayken, hem de bağımsız olmak ve aileden kopmak istemekte olduklarından yaşadıkları çatışma öfke duygusunu yaratabilmektedir (Eser \& Üstün, 2011: 113). Yetişkinlik döneminde ise rekabet ortamı, sorumluluğun yarattı̆̆ı yükümlülükler, diğer kişilerin haksız veya saygısız tavırlarına maruz kalma, toplum ya da çevre tarafından kabullenilmeme, evlilik ya da aile ilişkilerinde sorunlar yaşama gibi unsurlar engellenme ve buna bağlı olarak öfke duygusuna yol açabilir (Karataş \& Çelikkaleli, 2018: 456). Orta yaş ve ileri yaşlarda ise gelecek kaygısı ve belirsizliği, yaşın ilerlemesinin yarattı̆g kısıtlamalar engellenme hissine ve buna bağlı olarak öfkeye neden olabilir (Baltaş \& Baltaş, 2008).

Öfke duygusunun çocuğun sosyal ilişkilerinde son derece önemli bir etkisinin bulunduğu bilinmektedir (Tatlılığlu \& Karaca, 2013: 1104). Bu nedenle çocuğun öfkeyi ne sıklıkta yaşayacağı ve nasıl yansıtacağı gibi durumlar genellikle aile ortamında şekillenmektedir (Aydın \& Öztütüncü, 2001: 79). Ebeveynle kurulan ilk bağ bireyin sosyal ilişkilerini belirtildiği şekliyle etkileyebilmektedir. Bunun yanı sıra araştırmacıların büyük bir kısmına göre söz konusu bağ, bireyin diğerleri ile ilişkisini ve kendine yönelik algısını da etkilemektedir (Safran, 1990: 89). Erken dönemde bireyin bağlanma figürüyle kurmuş olduğu bağın niteliği, bireyin yetişkinlik döneminde kurduğu ilişkileri, "kim" olduğu ile ilgili fikirlerini ve benlik kavramını şekillendirmektedir (Çelik, 2006: 42).

Anne-babaların çocuklarını yetiştirme biçimleri kültürden kültüre ve toplumdan topluma farklılık göstermektedir (Özyürek vd., 2016: 1478). Örneğin Ortadoğu toplumları ile Bat1 toplumları kıyaslanırsa; Batı toplumunda çocukların çoğunlukla rekabet hisleri gelişmiş ve bağımsızlık seviyesi yüksek yetiştirildiği görülmekteyken, Ortadoğu toplumlarında ise çocukların ebeveynlerine daha bağımlı yetiştirildiği görülmektedir. Çocuk yetiştirme biçimleri hem toplumlara göre hem de ebeveynlere göre farklıdır, her ebeveynin çocuk yetiştirme biçimi kendine özgüdür (Şendil, 2003: 69).

Ebeveynlerin karakteristik özellikleri esas alınarak gerçekleştirilen bir meta analiz araştırmasında; kişisel özelliklerin anne-baba stili seçiminde çok önemli bir belirleyici olduğu neticesine varılmıştır. Beş faktör karakter özelliği dikkate alınarak gerçekleştirilen bu araştırmada, anne-baba tutumu olarak; uyumluluk ve dengeli duygusallık seviyesi, yeni deneyimlere açık olma, dışa dönüklük seviyesinin yüksek olması ile davranış denetimi ve duygusal sıcaklık arasında yakın bir ilişki bulunduğu saptanmıştır (Prinzie vd., 2009: 351). 
Bu çalışmada, 2-6 yaş arası çocuğu olan annelerin öfke düzeyinin çocuk yetiştirme tutumu üzerindeki etkisinin incelenmesi amaçlanmıştır. Bu doğrultuda belirlenen alt amaçlar ise 2-6 yaş arası çocuğu olan annelerin ciddiye alınmama, haksızlığa uğrama ve eleştirilme düzeylerinin çocuk yetiştirme tutumu üzerindeki etkisi incelemektir.

\section{Yöntem}

\section{Araştırmanın Modeli}

$\mathrm{Bu}$ araştırmanın modeli nicel araştırmalardan tarama modelidir (Mazlum \& Mazlum, 2017: 4). Araştırma beş bağımsız değişken, dört bağımlı değişkenden oluşmaktadır. Bağımsız değişkenler "Öfke Belirtileri", öfkeye yol açan durumlar alt boyutlarından "Ciddiye Alınmama", "Haksızlığa Uğrama", "Eleştirilme" ve "Beck Depresyon" ve bağımlı değiş̧kenler ebeveyn tutum ölçeği alt boyutlarında "Demokratik Tutum", "İzin Verici Tutum", "Aşırı Koruyucu Tutum" ve "Otoriter Tutum" olarak belirlenmiştir.

\section{Araştırmanın Katılımcıları}

Araştırmanın örneklemini evren içerisinden rastgele seçilen, İstanbul'da ikamet eden 112 katılımcı oluşturmaktadır.

Tablo 1: Anne ve Çocuklarının Ekonomik ve Demografik Özellikleri

\begin{tabular}{|c|c|c|c|}
\hline Demografik Özellik & & $\mathrm{F}$ & $\%$ \\
\hline \multirow{4}{*}{ Yaş } & 24-29 Yaş Arası & 24 & 21,4 \\
\hline & 30-36 Yaş Arası & 50 & 44,6 \\
\hline & 37-42 Yaş Arası & 35 & 31,3 \\
\hline & 43 Yaş ve Üzeri & 3 & 2,7 \\
\hline \multirow{4}{*}{ Çocuk Sayısı } & 1 Çocuk & 31 & 27,7 \\
\hline & 2-3 Çocuk & 64 & 57,1 \\
\hline & 4-5 Çocuk & 15 & 13,4 \\
\hline & 5 Çocuk Üzeri & 2 & 1,8 \\
\hline \multirow{6}{*}{ Eğitim } & İlkokul & 21 & 18,8 \\
\hline & Ortaokul & 22 & 19,6 \\
\hline & Lise & 26 & 23,2 \\
\hline & Önlisans & 11 & 9,8 \\
\hline & Lisans & 27 & 24,1 \\
\hline & Yüksek Lisans & 5 & 4,5 \\
\hline \multirow{2}{*}{ Çalışma Durumu } & Çalışmıyor & 73 & 65,2 \\
\hline & Çalışıyor & 39 & 34,8 \\
\hline \multirow{3}{*}{ Gelir } & Düşük & 16 & 14,2 \\
\hline & Orta & 48 & 42,9 \\
\hline & İyi & 48 & 42,9 \\
\hline \multirow{2}{*}{$\begin{array}{l}\text { Birlikte } \\
\text { Durumu }\end{array}$} & Birlikte Yaşıyor & 105 & 93,8 \\
\hline & Birlikte Yaşamıyor & 7 & 6,2 \\
\hline \multirow{6}{*}{ Evlilik Süresi } & 1-5 Y1l Aras1 & 17 & 15,2 \\
\hline & 6-10 Y1l Aras1 & 32 & 28,6 \\
\hline & 11-15 Y1l Aras 1 & 33 & 29,5 \\
\hline & 16-20 Y1l Aras1 & 19 & 17,0 \\
\hline & 21-25 Y1l Aras1 & 10 & 8,9 \\
\hline & 26 Y1l ve Üzeri & 1 & ,9 \\
\hline
\end{tabular}




\begin{tabular}{|c|c|c|c|}
\hline $\begin{array}{l}\text { Demografik } \\
\text { Özellik } \\
\end{array}$ & & $\mathrm{F}$ & $\%$ \\
\hline \multirow{2}{*}{$\begin{array}{l}2-6 \quad \text { Yaş } \\
\text { Cinsiyeti }\end{array}$} & Kadın & 70 & 62,5 \\
\hline & Erkek & 42 & 37,5 \\
\hline \multirow{5}{*}{$\begin{array}{lr}2-6 \quad \text { Yaş } & \text { Arası } \\
\text { Çocuklarının } & \text { Yaş } \\
\text { Durumu } & \end{array}$} & 2 Yaş & 16 & 14,3 \\
\hline & 3 Yaş & 32 & 28,6 \\
\hline & 4 Yaş & 16 & 14,3 \\
\hline & 5 Yaş & 29 & 25,9 \\
\hline & 6 Yaş & 19 & 17,0 \\
\hline \multirow{5}{*}{$\begin{array}{l}\text { Kaçıncı Çocuk 2-6 } \\
\text { Yaş Arasında }\end{array}$} & 1'inci Çocuk & 35 & 31,3 \\
\hline & 2'nci Çocuk & 33 & 29,5 \\
\hline & 3'üncü Çocuk & 30 & 26,8 \\
\hline & 4’üncü Çocuk & 11 & 9,8 \\
\hline & 5'inci Çocuk & 3 & 2,7 \\
\hline
\end{tabular}

\section{Veri Toplama Araçları}

Bu çalışma İstanbul Ticaret Üniversitesi Sosyal Bilimler Enstitüsü Aile Danışmanlığı ve Eğitimi alanında yüksek lisans tezinden üretilmiş bir çalışmadır. 2019 yılı şubat ayında İstanbul Ticaret Üniversitesi çalışalacak ve araştırma yapılacak her konu için etik kurul onayını zorunlu kılmamıştır. Üniversitesitemiz araştıracağım konuyu inceleyip kullanacağım ölçekleri değerlendirdikten sonra etik kurul onayına gerek olmadığına karar vemiştir. 2019 yılının şubat ayında tez çalışması için gerekli veriler toplanmaya başlamıştır.

$\mathrm{Bu}$ araştırmada veri toplama yöntemi olarak anket formu kullanılmıştır. Anket formu 4 bölümden oluşmaktadır.

Kişisel Bilgi Formu: Araştırmaya katılan anne ve çocuklarının kişisel bilgilerini elde etmeyi amaçlayan ve araştırmacı tarafından oluşturulan form 10 sorudan oluşmaktadır.

Çok Boyutlu Öfke Ölçeği: Balkaya ve Şahin (2003) tarafından uygulanmış olup öfkenin fiziksel belirtileri, öfkenin oluşmasına neden olan etmenleri, öfke ile ilgili düşünceleri, öfkeyle ilgili davranışları ve öfkelendiğinde sergilenen davranışları belirlemek ve katılımcılarının algılarını ölçmeyi amaçlamaktadır. Araştırmada 14 ifadeden oluşan Öfke Belirtileri Ölçeği ve 41 ifade ve 3 alt boyuttan oluşan Öfkeye Yol Açan Durumlar ölçeği kullanılmıştır. Ölçekler beşli likert ("1 = Kesinlikle Katılmıyorum", " 2 = Kat1lmıyorum", "3 = Kararsızım", " 4 = Kat1liyorum", "5 = Kesinlikle Katıliyorum") tiptedir. Bununla birlikte Öfkeye Yol Açan Durumlar Ölçeği alt boyutlarını "Ciddiye Alınmama (9, 17, 18, 19, 20, 23, 27, 28, 29, 30, 31, 32, 33, 35, 36, 37, 38, 39, 40 ve 41 nolu ifadeler)", "Haksızlığa Uğrama (4, 5, 6, 8, 11, 12, 13, 14, 15, 16, 21, 22, 24, 25, 26 ve 34 nolu ifadeler)" ve "Eleştirilme (1, 2, 3, 7 ve 10 nolu ifadeler)" oluşturmaktadır.

Öfke Belirtileri Ölçeğine verilen cevapların toplam güvenilirlik katsayısı (Cronbach's Alpha) 0,849 olarak belirlenmiştir.

Öfkeye Yol Açan Durumlar Ölçeğine verilen cevapların toplam güvenilirlik katsayısı (Cronbach's Alpha) 0,956 Öfkeye Yol Açan Durumlar Ölçeği alt boyutlarından ciddiye alınmamaya verilen cevapların toplam güvenilirlik katsayısı (Cronbach's Alpha) 0,842 , haksızlığa uğramaya verilen cevapların toplam güvenilirlik katsayısı (Cronbach's Alpha) 0,876 ve eleştirilmeye verilen cevapların toplam güvenilirlik katsayısı (Cronbach's Alpha) 0,751 olarak belirlenmiştir.

Ebeveyn Tutum Ölçeği: Demir ve Şendil (2008) tarafından geliştirilmiş olup 2-6 yaş arası çocuğa sahip katılımcıların çocuk yetiştirme davranışlarını ölçmeyi amaçlamaktadır. Araştırmada 46 ifade ve 4 alt boyuttan oluşan Öfkeye Yol Açan Durumlar ölçeği beşli likert ("1: Her zaman 
böyledir”, "2: Çoğu zaman böyledir", "3: Bazen böyledir”, “4: Nadiren böyledir”, "5: Hiçbir zaman böyle değildir") tiptedir. Ölçeğin alt boyutlarını "Demokratik Tutum $(2,5,6,7,10,13,14,15,18$, $20,23,25,29,36,38$ ve 42 nolu ifadeler), "İzin Verici Tutum" (1, 17, 24, 30, 31, 33, 34, 43 ve 44 nolu ifadeler), "Aşırı Koruyucu Tutum" (4, 8, 12, 16, 21, 22, 28, 41 ve 46 nolu ifadeler) ve "Otoriter Tutum" (3, 9, 11, 19, 26, 27, 32, 35, 39, 40 ve 45 nolu ifadeler) oluşturmaktadır.

Ebeveyn Tutum Ölçeğine verilen cevapların toplam güvenilirlik katsayısı (Cronbach's Alpha) 0,631 Ebeveyn Tutum Ölçeği alt boyutlarından demokratik tutuma verilen cevapların toplam güvenilirlik katsayısı (Cronbach's Alpha) 0,909, otoriter tutuma verilen cevapların toplam güvenilirlik katsayısı (Cronbach's Alpha) 0,859, aşırı koruyucu tutuma verilen cevapların toplam güvenilirlik katsayısı (Cronbach's Alpha) 0,796 ve izin verici tutuma verilen cevapların toplam güvenilirlik katsayısı (Cronbach's Alpha) 0,690 olarak belirlenmiştir.

Beck Depresyon Ölçeği: 1961 yılında Beck tarafından bireylerde depresyon belirtilerinin şiddetini ve riskini ölçek için klinik gözlem ve verilerle hazırlanmıştır. Gözlemlerin neticesinde 21 semptom altında birleştirilmiştir. 21 maddeden oluşan "Beck Depresyon Ölçeği" 0 ile 3 puan arasında puanlandırılmaktadır. Ölçeğe verilen cevapların neticesinde en düşük " 0 " puan ve en yüksek "63" puan alınabilmektedir. Ayrıca ölçekten alınan puanların artması katılımcıların depresyon seviyesinin arttığının göstergesi olarak kabul edilmektedir. Ölçekten alınan puanlara göre depresyon düzeyleri değerlendirmeleri irdelendiğinde;

- "0-13 puan arası depresyon yok"

- "14-19 puan arası düşük düzey depresyon”

- "20-28 puan arası orta düzey depresyon"

- “29-63 puan arası yüksek düzey depresyon” olarak değerlendirildiği belirlenmiştir (Varhan, 2017, s. 61-62).

Beck Depresyon Ölçeğine verilen cevapların toplam güvenilirlik katsayısı (Cronbach's Alpha) 0,905 olarak belirlenmiştir.

\section{Verilerin Analizi}

Tüm istatistiksel analizler SPSS (Statistical Package for the Social Sciences versiyon 25.0.0; SPSS Inc., Chicago, IL, ABD) programı ile yapılmıştır. Analizlerde tanımlayıcı istatistikler frekans $(\mathrm{f})$, yüzde $(\%)$, ortalama $(\overline{\mathrm{X}})$, standart sapma (SS), minimum ve maksimum değerler olarak belirtilmiştir. Ölçeklerin normal dağılım varsayımına uyup uymadığ katsayılarına bakarak belirlenmiştir (Tablo 1). Ayrıca normal dağılım gösteren değişkenlerin iki grup karşılaştırmalarında bağımsız örneklem t testi kullanılırken üç ve üzeri grupların karşılaştırmalarında tek yönlü varyans analizi (One-way ANOVA) testi kullanılmıştır. Araştırmanın problemleri doğrultusunda oluşturulan araştırmanın değişkenleri arasındaki ilişkiler Pearson Korelasyon testi ile incelenmiştir. Ayrıca korelasyon analizinden elde edilen bulgulara göre; Annelerin öfke ve depresyon düzeyi çocuk yetiştirme tutumu üzerinde etkisi lineer regresyon analizi ve çoklu doğrusal regresyon analizi ile incelenmiştir. Elde edilen tüm sonuçlar istatistiksel anlaml1l1k $\mathrm{p}<0,05$ düzeyinde değerlendirilmiştir.

\section{Bulgular}

Araştırmada; "Öfke Belirtileri", Öfkeye Yol Açan Durumlar Ölçeği alt boyutlarından "Ciddiye Alınmama", "Haksızlığa Uğrama" ve "Eleştirilme”, Ebeveyn Tutum Ölçeği alt boyutların "Demokratik Tutum”, “Otoriter Tutum”, “Aşırı Koruyucu Tutum” ve "İzin Verici Tutum”, "Beck Depresyon Envanteri" araştırmanın değişkenlerini oluşturmaktadır. Araştırmanın bu kısmında, araştırma değişkenlerine ilişkin tanımlayıcı istatistikler verilecek olup araştırma değişkenleri arasındaki ilişki ve etki irdelenecektir. 
Tablo 3: Araştırma Değişkenlerine İlişkin Betimsel Analiz Sonuçları

\begin{tabular}{llllllll}
\hline & N & Min. & Maks. & Ort. & SS & Çarpıklık & Basıklık \\
\hline Öfke Belirtileri & 112 & 14,00 & 38,00 & 22,55 & 5,98 &, 717 &,- 334 \\
Öfkeye Yol Açan Durumlar & 112 & 115,00 & 205,00 & 165,76 & 24,88 &,- 300 &,- 910 \\
Ciddiye Alınmama & 112 & 31,00 & 100,00 & 75,85 & 16,71 &,- 446 &,- 337 \\
Haksıllığa Uğrama & 112 & 54,00 & 80,00 & 71,75 & 7,55 &,- 908 &,- 234 \\
Eleştirilme & 112 & 6,00 & 25,00 & 17,65 & 4,24 &,- 363 &,- 350 \\
Ebeveyn Tutumu & 112 & 101,00 & 158,00 & 128,85 & 11,24 &, 010 &, 119 \\
$\quad$ Demokratik Tutum & 112 & 16,00 & 47,00 & 28,79 & 7,85 &, 365 &,- 469 \\
Otoriter Tutum & 112 & 33,00 & 55,00 & 44,92 & 5,19 &,- 454 &,- 204 \\
imAşırı Koruyucu Tutum & 112 & 9,00 & 38,00 & 21,57 & 6,67 &, 369 &, 035 \\
$\quad$ İzin Verici Tutum & 112 & 21,00 & 45,00 & 32,83 & 5,15 &,- 634 &, 151 \\
Beck Depresyon Envanteri & 112 &, 00 & 16,00 & 3,66 & 5,10 & 1,352 &, 574 \\
\hline
\end{tabular}

Araştırmaya katılan annelerin, öfke belirtilerine verdiği cevapların toplam ortalaması $22,55 \pm 5,98$, minimum puanı 14,00 ve maksimum puanı 38,00 olarak tespit edilmiştir.

Araştırmaya katılan annelerin, öfkeye yol açan durumlara verdiği cevapların toplam ortalamas $165,76 \pm 24,88$, minimum puan 115,00 ve maksimum puan 205,00 olarak tespit edilmiştir. Ayrıca öfkeye yol açan durumlar alt faktörlerinden olan ciddiye alınmamaya verdiği cevapların toplam ortalamas $175,85 \pm 16,71$, minimum puan 131,00 ve maksimum puan 100,00 , haksızlığa uğramaya verdiği cevapların toplam ortalaması $71,75 \pm 7,55$, minimum puanı 54,00 ve maksimum puanı 80,00 ve eleştirilmeye verdiği cevapların toplam ortalaması $17,65 \pm 4,24$, minimum puanı 6,00 ve maksimum puanı 25,00 olarak tespit edilmiştir.

Araştırmaya katılan annelerin, çocuk yetirme tutumuna verdiği cevapların toplam ortalamas $128,85 \pm 11,24$, minimum puan 101,00 ve maksimum puan 158,00 olarak tespit edilmiştir. Ayrıca çocuk yetiştirme tutumu alt faktörlerinden olan demokratik tutuma verdiği cevapların toplam ortalamas $28,79 \pm 7,85$, minimum puan1 16,00 ve maksimum puan1 47,00 , otoriter tutuma verdiği cevapların toplam ortalaması 44,92 $\pm 5,19$, minimum puanı 33,00 ve

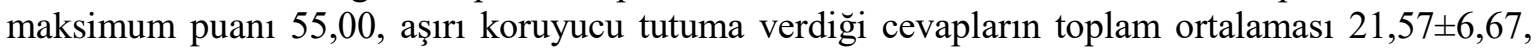
minimum puan 9,00 ve maksimum puan 38,00 ve izin verici tutuma verdiği cevapların toplam ortalaması $32,83 \pm 5,15$, minimum puanı 21,00 ve maksimum puanı 45,00 olarak tespit edilmiştir.

Araştırmaya katılan annelerin, beck depresyon envanterine verdiği cevapların toplam ortalamas $13,66 \pm 5,10$, minimum puanı 0,00 ve maksimum puanı 16,00 olarak tespit edilmiştir. Ayrıca bulunan toplam ortalamaya göre; araştırmaya katılan annelerde depresyon olmadığı sonucuna ulaşılmıştır.

Seçer (2015) tarafından "normal dağılım varsayımında; "çarpıklık ve basıklık" değerleri değerlendirilerek dağılımın normalliğine karar verilmesinin daha doğru bir yaklaşım" olduğu değerlendirilmiştir. Doğan ve Başokçu (2010) "ölçeklerin çarpıklık ve basıklık değerlerinin $+1,5$ ve $-1,5$ değerleri arasında olması değişkenlerin normal dağılıma uyum gösterdiğini ifade ettiğini”" 
belirtmektedir. Bununla birlikte George ve Mallery (2010) bu değer aralıklarının daha geniş olduğu (Skewness ve Kurtosis +2.0 ile -2.0 aralığında) ve kabul gördüğü ifade etmektedir. Sonuç olarak yapılan analizler sonucunda değişkenlerin tamamının belirtilen aralıklarda olduğu, aşırı uç değerlerin olmadığı ve normal dağılım varsayımını sağladığı tespit edilmiş olup parametrik testlerin uygulanabilirliği sonucuna varılmıştır.

\section{Anne ve Çocuklarının Demografik Profili ile Araştırma Değişkenleri Arasındaki İlişkilere Yönelik Bulgular}

Çalışmanın bu bölümünde araştırma grubunu oluşturan anne ve 2-6 yaş arası çocuklarının demografik özellikleri ile araştırma değişkenleri düzeyleri arasındaki farklılaşmaları irdelenecektir.

Tablo 4: 2-6 Yaş Arası Çocuğu Olan AnnelerinYaşı ile Araştırma Değişkenleri Arasındaki İlişkiye Yönelik Bağımsız Örneklem t testi Sonuçları

\begin{tabular}{|c|c|c|c|c|c|c|c|}
\hline Alt Boyutlar & Yaş Durumu & $\mathrm{n}$ & Ort. & SS & $T$ & $p$ & $\begin{array}{l}\text { Levene's } \\
\text { Testi }\end{array}$ \\
\hline \multirow[b]{2}{*}{ Öfke Belirtileri } & 24-36 Yaş Arası & 74 & 22,68 & 6,03 & \multirow[b]{2}{*}{, 300} & \multirow[b]{2}{*}{, 765} & \multirow[b]{2}{*}{,643 } \\
\hline & 37 Yaş Üzeri & 38 & 22,32 & 5,96 & & & \\
\hline \multirow[b]{2}{*}{ Ciddiye Alınmama } & 24-36 Yaş Arası & 74 & 74,43 & 15,86 & \multirow[b]{2}{*}{$-1,254$} & \multirow[b]{2}{*}{,212 } & \multirow[b]{2}{*}{,282 } \\
\hline & 37 Yaş Üzeri & 38 & 78,61 & 18,16 & & & \\
\hline \multirow[b]{2}{*}{ Haksızlığa Uğrama } & 24-36 Yaş Arası & 74 & 70,96 & 7,95 & \multirow[b]{2}{*}{$-1,556$} & \multirow[b]{2}{*}{,123 } & \multirow[b]{2}{*}{, 244} \\
\hline & 37 Yaş Üzeri & 38 & 73,29 & 6,53 & & & \\
\hline \multirow[b]{2}{*}{ Eleştirilme } & 24-36 Yaş Arası & 74 & 17,50 & 4,36 & \multirow[b]{2}{*}{,- 527} & \multirow[b]{2}{*}{, 599} & \multirow[b]{2}{*}{, 739} \\
\hline & 37 Yaş Üzeri & 38 & 17,95 & 4,05 & & & \\
\hline \multirow[b]{2}{*}{ Demokratik Tutum } & 24-36 Yaş Arası & 74 & 27,47 & 7,53 & \multirow[b]{2}{*}{$-2,530$} & \multirow[b]{2}{*}{, 013} & \multirow[b]{2}{*}{, 809} \\
\hline & 37 Yaş Üzeri & 38 & 31,34 & 7,91 & & & \\
\hline \multirow{2}{*}{ Otoriter Tutum } & 24-36 Yaş Arası & 74 & 45,49 & 5,30 & \multirow{2}{*}{1,625} & \multirow{2}{*}{,107 } & \multirow{2}{*}{, 533} \\
\hline & 37 Yaş Üzeri & 38 & 43,82 & 4,85 & & & \\
\hline \multirow{2}{*}{ Aşırı Koruyucu Tutum } & 24-36 Yaş Arası & 74 & 20,97 & 6,35 & \multirow{2}{*}{$-1,329$} & \multirow{2}{*}{, 187} & \multirow{2}{*}{,199 } \\
\hline & 37 Yaş Üzeri & 38 & 22,74 & 7,21 & & & \\
\hline \multirow{2}{*}{ İzin Verici Tutum } & 24-36 Yaş Arası & 74 & 32,88 & 5,03 & \multirow{2}{*}{, 137} & \multirow{2}{*}{,891 } & \multirow{2}{*}{,684 } \\
\hline & 37 Yaş Üzeri & 38 & 32,74 & 5,45 & & & \\
\hline \multirow{2}{*}{ Beck Depresyon } & 24-36 Yaş Arası & 74 & 4,01 & 5,41 & \multirow{2}{*}{1,021} & \multirow{2}{*}{,309 } & \multirow{2}{*}{, 671} \\
\hline & 37 Yaş Üzeri & 38 & 2,97 & 4,44 & & & \\
\hline
\end{tabular}

Tablo 4'te gerçekleştirilen bağımsız örneklem t testi sonuçlarına göre; araştırma grubunu oluşturan annelerin yaşına göre demokratik tutum düzeyleri istatistiksel olarak anlamlı farklılaşmaktadır $(\mathrm{t}=-2,530, \mathrm{p}=0.013)$. Ayrıca 37 yaş ve üzeri olan annelerin demokratik tutum 
düzeyi 24-36 yaş arası annelere göre daha yüksektir. Bununla birlikte araştırma grubunu oluşturan annelerin yaşına göre öfke belirtileri, ciddiye alınmama, haksızlığa uğrama, eleştirilme, otoriter tutum, aşırı koruyucu tutum, izin verici tutum ve depresyon düzeyleri istatistiksel olarak anlamlı farklılaşmamaktadır ( $p>0.05$ ). Analizden elde edilen bilgiler neticesinde $24-36$ yaş arası ya da 37 yaş ve üzeri anne olmak; araştırma grubunu oluşturan annelerin demokratik tutum düzeylerini etkilerken annelerin öfke belirtileri, ciddiye alınmama, haksızlığa uğrama, eleştirilme, otoriter tutum, aşırı koruyucu tutum, izin verici tutum ve depresyon düzeylerini etkilememektedir (Tablo 4).

Bağımsız örneklem t testi sonuçlarına göre; araştırma grubunu oluşturan annelerin 2-6 yaş arası çocuk sayısına göre demokratik tutum ve otoriter tutum düzeyleri istatistiksel olarak anlamlı farklılaşmaktadır (Sırasıyla; $\mathrm{t}=-2,841, \mathrm{p}=0.005 ; \mathrm{t}=2,698, \mathrm{p}=0.008$ ). Ayrıca 1 çocuğu olan annelerin otoriter tutum düzeyi 2 ve üzeri çocuğu olan annelere daha yüksekken 2 ve üzeri çocuğu olan annelerin demokratik tutum düzeyi 1 çocuğu olan annelere göre yüksektir. Bununla birlikte araştırma grubunu oluşturan annelerin çocuk sayısına göre öfke belirtileri, ciddiye alınmama, haksızlığa uğrama, eleştirilme, aşırı koruyucu tutum, izin verici tutum ve depresyon düzeyleri istatistiksel olarak anlamlı farklılaşmamaktadır ( $>0.05)$. Analizden elde edilen bilgiler neticesinde annelerin 1 çocuğunun ya da 2 ve üzeri çocuğunun olması; araştırma grubunu oluşturan annelerin demokratik tutum ve otoriter tutum düzeylerini etkilerken annelerin öfke belirtileri, ciddiye alınmama, haksızlığa uğrama, eleştirilme, aşırı koruyucu tutum, izin verici tutum ve depresyon düzeylerini etkilememektedir.

Tablo 5: Annelerin 2-6 Yaş Arasındaki Çocuklarının Cinsiyeti ile Araştırma Değişkenleri Arasındaki İlişkiye Yönelik Bağımsız Örneklem T testi Sonuçları

\begin{tabular}{|c|c|c|c|c|c|c|c|}
\hline Alt Boyutlar & Çocuklarının Cinsiyeti & $\mathrm{n}$ & Ort. & SS & $T$ & $P$ & $\begin{array}{l}\text { Levene's } \\
\text { Testi }\end{array}$ \\
\hline \multirow{3}{*}{ Öfke Belirtileri } & Kadın & 70 & 22,09 & 5,57 & \multirow{3}{*}{$-1,069$} & \multirow{3}{*}{,287 } & \multirow{3}{*}{, 210} \\
\hline & & & & & & & \\
\hline & Erkek & 42 & 23,33 & 6,61 & & & \\
\hline \multirow{3}{*}{ Ciddiye Alınmama } & Kadın & 70 & 77,29 & 16,81 & \multirow{3}{*}{1,177} & \multirow{3}{*}{, 242} & \multirow{3}{*}{,935 } \\
\hline & & & & & & & \\
\hline & Erkek & 42 & 73,45 & 16,47 & & & \\
\hline \multirow{3}{*}{ Haksızlığa Uğrama } & Kadın & 70 & 72,36 & 7,41 & \multirow{3}{*}{1,100} & \multirow{3}{*}{, 274} & \multirow{3}{*}{, 329} \\
\hline & & & & & & & \\
\hline & Erkek & 42 & 70,74 & 7,76 & & & \\
\hline \multirow[b]{2}{*}{ Eleştirilme } & Kadın & 70 & 17,57 & 4,56 & \multirow[b]{2}{*}{,- 258} & \multirow[b]{2}{*}{,797 } & \multirow[b]{2}{*}{, 179} \\
\hline & Errol & 12 & 1770 & 371 & & & \\
\hline \multirow[b]{3}{*}{ Demokratik Tutum } & & & & & & \multirow[b]{3}{*}{,489 } & \multirow[b]{3}{*}{, 239} \\
\hline & Kadın & 70 & 29,19 & 8,65 & \multirow[b]{2}{*}{,695 } & & \\
\hline & Erkek & 42 & 2812 & 632 & & & \\
\hline \multirow{3}{*}{ Otoriter Tutum } & & & & & & & \\
\hline & Kadın & 70 & 44,96 & 5,68 & \multirow{2}{*}{,098 } & \multirow{2}{*}{,922 } & \multirow{2}{*}{, 101} \\
\hline & Erkek & 42 & 44,86 & 4,30 & & & \\
\hline \multirow{2}{*}{ Aşırı Koruyucu Tutum } & Kadın & 70 & 21,70 & 6,50 & \multirow{2}{*}{,262 } & \multirow{2}{*}{,794 } & \multirow[b]{2}{*}{,656 } \\
\hline & Erkek & 42 & 21,36 & 7,03 & & & \\
\hline
\end{tabular}




\begin{tabular}{lllllllll}
\hline \multirow{2}{*}{ İzin Verici Tutum } & Kadın & 70 & 32,99 & 5,39 & & & \\
& Erkek & 42 & 32,57 & 4,77 & & &, 611 &, 627 \\
\hline \multirow{3}{*}{ Beck Depresyon } & Kadın & 70 & 3,46 & 4,95 & & & \\
& Erkek & 42 & 4,00 & 5,40 & & &, 588 &, 468 \\
& & & & & \\
\hline
\end{tabular}

Tablo 5'te gerçekleştirilen bağımsız örneklem t testi sonuçlarına göre; araştırma grubunu oluşturan annelerin 2-6 yaş arası çocuğunun cinsiyetine göre öfke belirtileri, ciddiye alınmama, haksızlığa uğrama, eleştirilme, demokratik tutum, otoriter tutum, aşırı koruyucu tutum, izin verici tutum ve depresyon düzeyleri istatistiksel olarak anlamlı farklılaşmamaktadır ( $p>0.05)$. Analizden elde edilen bilgiler neticesinde annelerin 2-6 yaş arası çocuklarının kadın ya da erkek olması; araştırma grubunu oluşturan annelerin öfke belirtileri, ciddiye alınmama, haksızlığa uğrama, eleştirilme, demokratik tutum, otoriter tutum, aşırı koruyucu tutum, izin verici tutum ve depresyon düzeylerini etkilememektedir.

Tek yönlü varyans analiz sonuçlarına göre; araştırma grubunu oluşturan annelerin eğitimine göre haksızlığa uğrama, demokratik tutum ve otoriter tutum düzeyleri istatistiksel olarak anlamlı farklılaşmaktadır (Sirasıyla; $\mathrm{F}=3,074, \mathrm{p}=0.050 ; \mathrm{F}=9,644, \mathrm{p}<0.001 ; \mathrm{F}=8,251, \mathrm{p}<0.001$ ). Bununla birlikte araştırma grubunu oluşturan annelerin eğitimine göre öfke belirtileri, ciddiye alınmama, eleştirilme, aşırı koruyucu tutum, izin verici tutum ve depresyon düzeyleri istatistiksel olarak anlamlı farklılaşmamaktadır $(\mathrm{p}>0.05)$. Analizden elde edilen bilgiler neticesinde annelerin eğitimi; araştırma grubunu oluşturan annelerin haksızlığa uğrama, demokratik tutum ve otoriter tutum düzeylerini etkilerken annelerin öfke belirtileri, ciddiye alınmama, eleştirilme, aşırı koruyucu tutum, izin verici tutum ve depresyon düzeylerini etkilememektedir.

Tablo 6: 2-6 Yaş Arası Çocuğu Olan AnnelerinÇalışma Durumu ile Araştırma Değişkenleri Arasındaki İlişkiye Yönelik Bağımsız Örneklem T testi Sonuçları

\begin{tabular}{|c|c|c|c|c|c|c|c|}
\hline Alt Boyutlar & Çalışma Durumu & $\mathrm{n}$ & Ort. & SS & $t$ & $P$ & $\begin{array}{l}\text { Levene's } \\
\text { Testi }\end{array}$ \\
\hline \multirow[b]{2}{*}{ Öfke Belirtileri } & Çalışmıyor & 73 & 22,01 & 5,60 & \multirow[b]{2}{*}{$-1,311$} & \multirow[b]{2}{*}{,193 } & \multirow[b]{2}{*}{, 144} \\
\hline & Calıșiyor & 39 & 23,56 & 6,60 & & & \\
\hline \multirow[b]{2}{*}{ Ciddiye Alınmama } & Çalışmıyor & 73 & 76,25 & 17,11 & \multirow[b]{2}{*}{, 344} & \multirow[b]{2}{*}{, 732} & \multirow[b]{2}{*}{, 671} \\
\hline & Çalışıyor & 39 & 75,10 & 16,12 & & & \\
\hline \multirow{2}{*}{ Haksızlığa Uğrama } & Çalışmıyor & 73 & 71,78 & 7,69 & \multirow{2}{*}{, 059} & \multirow{2}{*}{,953 } & \multirow{2}{*}{,899 } \\
\hline & Çalışıyor & 39 & 71,69 & 7,38 & & & \\
\hline \multirow{2}{*}{ Eleştirilme } & Çalışmıyor & 73 & 17,44 & 4,36 & \multirow{2}{*}{,- 727} & \multirow{2}{*}{,469 } & \multirow{2}{*}{,980 } \\
\hline & Çalışıyor & 39 & 18,05 & 4,03 & & & \\
\hline \multirow{2}{*}{ Demokratik Tutum } & Çalışmıyor & 73 & 30,30 & 7,93 & \multirow{2}{*}{2,888} & \multirow{2}{*}{, 005} & \multirow{2}{*}{,203 } \\
\hline & Çalışıyor & 39 & 25,95 & 6,94 & & & \\
\hline Otoriter Tutum & Çalışmıyor & 73 & 44,41 & 5,19 & $-1,426$ &, 157 & ,994 \\
\hline
\end{tabular}




\begin{tabular}{|c|c|c|c|c|c|c|c|}
\hline & Çalışıyor & 39 & 45,87 & 5,12 & & & \\
\hline \multirow{2}{*}{ Aşırı Koruyucu Tutum } & Çalışmıyor & 73 & 21,37 & 6,53 & \multirow{2}{*}{,- 436} & \multirow{2}{*}{,664 } & \multirow{2}{*}{, 729} \\
\hline & Çalışıyor & 39 & 21,95 & 7,00 & & & \\
\hline \multirow{2}{*}{ İzin Verici Tutum } & Çalışmıyor & 73 & 33,47 & 5,06 & \multirow{2}{*}{1,805} & \multirow{2}{*}{,074 } & \multirow{2}{*}{,652 } \\
\hline & Çalışıyor & 39 & 31,64 & 5,16 & & & \\
\hline \multirow[b]{2}{*}{ Beck Depresyon } & Çalışmıyor & 73 & 3,38 & 5,24 & \multirow[b]{2}{*}{,- 785} & \multirow[b]{2}{*}{,434 } & \multirow[b]{2}{*}{,902 } \\
\hline & Çalışıyor & 39 & 4,18 & 4,86 & & & \\
\hline
\end{tabular}

Tablo 6'da gerçekleştirilen bağımsız örneklem $\mathrm{t}$ testi sonuçlarına göre; araştırma grubunu oluşturan annelerin çalışma durumuna göre demokratik tutum düzeyleri istatistiksel olarak anlamlı farklılaşmaktadır $(\mathrm{t}=2,888, \mathrm{p}=0.005)$. Ayrıca çalışmayan annelerin demokratik tutum düzeyi çalışan annelere göre daha yüksektir. Bununla birlikte araştırma grubunu oluşturan annelerin çalışma durumuna göre öfke belirtileri, ciddiye alınmama, haksızlığa uğrama, eleştirilme, otoriter tutum, aşırı koruyucu tutum, izin verici tutum ve depresyon düzeyleri istatistiksel olarak anlamlı farklılaşmamaktadır $(\mathrm{p}>0.05)$. Analizden elde edilen bilgiler neticesinde annelerin çalışması ya da çalışmaması; araştırma grubunu oluşturan annelerin demokratik tutum düzeylerini etkilerken annelerin öfke belirtileri, ciddiye alınmama, haksızlığa uğrama, eleştirilme, otoriter tutum, aşırı koruyucu tutum, izin verici tutum ve depresyon düzeylerini etkilememektedir

Tablo 7:“"Hane Gelir Düzeyi ile Araştırma Değişkenleri Arasındaki İlişkiye Yönelik Bağımsız Örneklem T testi Sonuçları

\begin{tabular}{|c|c|c|c|c|c|c|c|}
\hline Alt Boyutlar & Gelir Düzeyi & $\mathrm{n}$ & Ort. & SS & $t$ & $p$ & $\begin{array}{l}\text { Levene's } \\
\text { Testi }\end{array}$ \\
\hline \multirow[b]{2}{*}{ Öfke Belirtileri } & Orta/Düşük & 64 & 23,58 & 6,26 & \multirow[b]{2}{*}{2,126} & \multirow[b]{2}{*}{,036 } & \multirow[b]{2}{*}{,302 } \\
\hline & & 48 & & & & & \\
\hline \multirow[b]{2}{*}{ Ciddiye Alınmama } & Orta/Düşük & 64 & 75,14 & 18,52 & \multirow[b]{2}{*}{,- 516} & \multirow[b]{2}{*}{,607 } & \multirow[b]{2}{*}{, 248} \\
\hline & & 48 & 76,79 & & & & \\
\hline \multirow[b]{2}{*}{ Haksızlığa Uğrama } & Orta/Düşük & 64 & 71,22 & 7,99 & \multirow[b]{2}{*}{,- 859} & \multirow[b]{2}{*}{,392 } & \multirow[b]{2}{*}{, 142} \\
\hline & Yüksek & 48 & 72,46 & & & & \\
\hline \multirow[b]{2}{*}{ Eleştirilme } & Orta/Düşük & 64 & 17,72 & 4,57 & \multirow[b]{2}{*}{, 192 } & \multirow[b]{2}{*}{,848 } & \multirow[b]{2}{*}{, 367} \\
\hline & Yüksek & 48 & 17,56 & & & & \\
\hline \multirow[b]{2}{*}{ Demokratik Tutum } & Orta/Düşük & 64 & 29,77 & 8,12 & \multirow[b]{2}{*}{1,535} & \multirow[b]{2}{*}{,128 } & \multirow[b]{2}{*}{,694 } \\
\hline & Yüksek & 48 & 27,48 & 7,34 & & & \\
\hline \multirow[b]{2}{*}{ Otoriter Tutum } & Orta/Düşük & 64 & 43,63 & 5,64 & \multirow[b]{2}{*}{$-3,171$} & \multirow[b]{2}{*}{,002 } & \multirow[b]{2}{*}{,219 } \\
\hline & Yüksek & 48 & 46,65 & 3,96 & & & \\
\hline Aşırı Koruyucu Tutum & Orta/Düşük & 64 & 22,13 & 6,74 & 1,014 & ,313 & 898 \\
\hline
\end{tabular}




\begin{tabular}{|c|c|c|c|c|c|c|c|}
\hline & Yüksek & 48 & 20,83 & 6,58 & & & \\
\hline \multirow[b]{2}{*}{ İzin Verici Tutum } & Orta/Düşük & 64 & 32,69 & 5,41 & \multirow[b]{2}{*}{,- 338} & \multirow[b]{2}{*}{,736 } & \multirow[b]{2}{*}{,219 } \\
\hline & Yüksek & 48 & 33,02 & 4,84 & & & \\
\hline \multirow[b]{2}{*}{ Beck Depresyon } & Orta/Düşük & 64 & 4,39 & 5,61 & \multirow[b]{2}{*}{1,764} & \multirow[b]{2}{*}{, 080} & \multirow[b]{2}{*}{,321 } \\
\hline & Yüksek & 48 & 2,69 & 4,20 & & & \\
\hline
\end{tabular}

Tablo 7'de gerçekleştirilen bağımsız örneklem $\mathrm{t}$ testi sonuçlarına göre; araştırma grubunu oluşturan annelerin hanesine giren gelir durumuna göre öfke belirtileri ve otoriter tutum düzeyleri istatistiksel olarak anlamlı farklılaşmaktadır (Sirasıyla; $\mathrm{t}=2,126, \mathrm{p}=0.036 ; \mathrm{t}=-3,171, \mathrm{p}=0.002$ ). Ayrıca yüksek geliri olan annelerin otoriter tutum düzeyi orta/düşük geliri olan annelere daha yüksekken orta/düşük geliri olan annelerin öfke belirtileri düzeyi yüksek geliri olan annelere göre yüksektir. Bununla birlikte araştırma grubunu oluşturan annelerin hanesine giren gelire göre ciddiye alınmama, haksızlığa uğrama, eleştirilme, demokratik tutum, aşırı koruyucu tutum, izin verici tutum ve depresyon düzeyleri istatistiksel olarak anlamlı farklılaşmamaktadır ( $>0.05)$. Analizden elde edilen bilgiler neticesinde annelerin hanesine gire gelirin orta/düşük ya da yüksek olması; araştırma grubunu oluşturan annelerin öfke belirtileri ve otoriter tutum düzeylerini etkilerken annelerin ciddiye alınmama, haksızlığa uğrama, eleştirilme, demokratik tutum ve aşırı koruyucu tutum, izin verici tutum ve depresyon düzeylerini etkilememektedir. Tek yönlü varyans analiz sonuçlarına göre; araştırma grubunu oluşturan annelerin kaç yıldır evli olduğuna göre demokratik tutum düzeyleri istatistiksel olarak anlamlı farklılaşmaktadır ( $\mathrm{F}=5,003, \mathrm{p}=0.008)$. Bununla birlikte araştırma grubunu oluşturan annelerin kaç yıldır evli olduğuna göre öfke belirtileri, ciddiye alınmama, haksızlığa uğrama, eleştirilme, otoriter tutum, aşırı koruyucu tutum, izin verici tutum ve depresyon düzeyleri istatistiksel olarak anlamlı farklılaşmamaktadır ( $>0.05$ ). Analizden elde edilen bilgiler neticesinde annelerin kaç yıldır evli olduğu; araştırma grubunu oluşturan annelerin demokratik tutum düzeylerini etkilerken annelerin öfke belirtileri, ciddiye alınmama, haksızlığa uğrama, eleştirilme, otoriter tutum, aşırı koruyucu tutum, izin verici tutum ve depresyon düzeylerini etkilememektedir.

\section{Araştırma Değişkenleri Arasındaki İlişkilere Yönelik Bulgular}

Araştırmanın bu bölümünde, araştırma değişkenlerinin birbiri arasındaki ilişkileri, Pearson Korelasyon Analizi ile incelenecektir (Tablo 8). Aralarında ilişki çıkması durumunda annelerin depresyon düzeyinin, öfke belirtilerinin ve öfkeye yol açan durumların çocuk yetiştirme tutumu üzerindeki etkisi regresyon analizi ile incelenecektir.

Tablo 8: Pearson Korelasyon Analizi Sonuçları

\begin{tabular}{lllllllllll}
\hline & & 1. & 2. & 3. & 4. & 5. & 6. & 7. & 8. & 9. \\
\hline \multirow{2}{*}{ 1. Öfke Belirtileri } & K.K. & 1 &,- 109 &,- 098 &, 029 &, 098 &,$- 244^{* *}$ &, $232^{*}$ &,- 064 &, $460^{* *}$ \\
& P & &, 253 &, 302 &, 759 &, 304 &, 009 &, 014 &, 505 &, 000 \\
\hline \multirow{2}{*}{ 2. Ciddiye Alınmama } & K.K. & 1 &, $755^{* *}$ &, $644^{* *}$ &,- 051 &,- 048 &,$- 315^{* *}$ &, 123 &,- 127 \\
& P & & &, 000 &, 000 &, 595 &, 613 &, 001 &, 195 &, 180 \\
\hline \multirow{2}{*}{ 3. Haksızlığa Uğrama } & K.K. & & 1 &, $668^{* *}$ &,- 081 &, 045 &,$- 236^{*}$ &, 178 &,- 163 \\
& P & & &, 000 &, 397 &, 639 &, 012 &, 061 &, 087 \\
\hline 4. Eleştirilme & K.K. & & & 1 &,- 006 &,- 060 &,- 028 &, $257^{* *}$ &,- 061
\end{tabular}




\begin{tabular}{|c|c|c|c|c|c|c|}
\hline & $\mathrm{p}$ & ,947 &, 531 &, 773 &, 006 &, 521 \\
\hline \multirow{2}{*}{ 5. Demokratik Tutum } & K.K. & 1 &,$- 612^{* *}$ &, $255^{* *}$ &,$- 380^{* *}$ &,- 044 \\
\hline & $\mathrm{p}$ & & ,000 &, 007 &, 000 & ,644 \\
\hline \multirow{2}{*}{ 6. Otoriter Tutum } & K.K. & & 1 &,- 098 &, $438^{* *}$ &,- 117 \\
\hline & $\mathrm{p}$ & & & ,306 &, 000 & 219 \\
\hline \multirow{2}{*}{$\begin{array}{l}\text { 7. Aşırı Koruyucu } \\
\text { Tutum }\end{array}$} & K.K. & & & 1 &,- 027 &, 001 \\
\hline & $\mathrm{P}$ & & & &, 777 & ,994 \\
\hline \multirow{2}{*}{ 8. İzin Verici Tutum } & K.K. & & & & 1 &,- 119 \\
\hline & $\mathrm{p}$ & & & & &, 211 \\
\hline \multirow{2}{*}{ 9. Beck Depresyon } & K.K. & & & & & 1 \\
\hline & $\mathrm{p}$ & & & & & \\
\hline
\end{tabular}

$* * \mathrm{p}<0.01 \quad * \mathrm{p}<0.05$

Araştırma grubunu oluşturan annelerin, öfke belirtileri düzeyi ile aşırı koruyucu tutum ve depresyon düzeyi arasında pozitif yönlü korelasyon varken öfke belirtileri düzeyi ile otoriter tutum düzeyi arasında negatif yönlü korelasyon vardır $(\mathrm{p}<0.05)$. Ayrıca annelerin öfke belirtileri düzeyi ile ciddiye alınmama, haksızlığa uğrama, eleștirilme, demokratik tutum ve izin verici tutum düzeyleri arasında korelasyon saptanmamıştır ( $\mathrm{p}>0.05)$.

Araştırma grubunu oluşturan annelerin, ciddiye alınmama düzeyi ile haksızlığa uğrama ve eleştirilme düzeyleri arasında pozitif yönlü korelasyon varken ciddiye alınmama düzeyi ile aşırı koruyucu tutum düzeyi arasında negatif yönlü korelasyon vardır $(\mathrm{p}<0.05)$. Ayrıca annelerin ciddiye alınmama düzeyi ile demokratik tutum, otoriter tutum, izin verici tutum ve depresyon düzeyleri arasında korelasyon saptanmamıştır ( $\mathrm{p}>0.05)$.

Araştırma grubunu oluşturan annelerin, haksızlığa uğrama düzeyi ile eleştirilme düzeyleri arasında pozitif yönlü korelasyon varken haksızlığa uğrama düzeyi ile aşırı koruyucu tutum düzeyi arasında negatif yönlü korelasyon vardır $(\mathrm{p}<0.05)$. Ayrıca annelerin haksızlığa uğrama düzeyi ile demokratik tutum, otoriter tutum, izin verici tutum ve depresyon düzeyleri arasinda korelasyon saptanmamıştır ( $\mathrm{p}>0.05)$.

Araştırma grubunu oluşturan annelerin, eleştirilme düzeyi ile izin verici tutum düzeyleri arasında pozitif yönlü düşük düzeyde korelasyon vardır $(\mathrm{r}=0,257, \mathrm{p}=0.006)$. Ayrıca annelerin eleştirilme düzeyi ile demokratik tutum, otoriter tutum, aşırı koruyucu tutum ve depresyon düzeyleri arasında korelasyon saptanmamıştır ( $\mathrm{p}>0.05)$.

Araştırma grubunu oluşturan annelerin, demokratik tutum düzeyi ile aşırı koruyucu tutum düzeyi arasında pozitif yönlü korelasyon varken demokratik tutum düzeyi ile otoriter tutum ve izin verici tutum düzeyleri arasında negatif yönlü korelasyon vardır $(\mathrm{p}<0.05)$. Ayrıca annelerin demokratik tutum düzeyi ile depresyon düzeyleri arasında korelasyon saptanmamıştır $(p>0.05)$.

Araştırma grubunu oluşturan annelerin, otoriter tutum düzeyi ile izin verici tutum düzeyi arasında pozitif yönlü orta düzeyde korelasyon vardır $(\mathrm{r}=438, \mathrm{p}<0.001)$. Ayrıca annelerin otoriter tutum düzeyi ile aşırı koruyucu tutum ve depresyon düzeyleri arasında korelasyon saptanmamıştır $(\mathrm{p}>0.05)$.

Araştırma grubunu oluşturan annelerin aşırı koruyucu tutum düzeyi ile izin verici tutum ve depresyon düzeyleri arasında korelasyon saptanmamıştır ( $p>0.05)$. 
Araştırma grubunu oluşturan annelerin izin verici tutum düzeyi ile depresyon düzeyleri arasında korelasyon saptanmamıştır ( $\mathrm{p}>0.05)$.

"Regresyon analizlerinden önce, veri setine ilişkin doğrusallık, normallik ve homojenlik varsayımları incelenmiştir. Veri setinde uç değerlerin (outliers) olup olmadığı incelenmiş ve aşırı uç değerlerin olmadığı saptanmıştır. Standart hatalar arasında otokorelasyon olup olmadığını saptamak için Durbin-Watson istatistiğinden yararlanılmış, Durbin-Watson istatistiği 1,981-2,303 aralığında olduğu için hatalar arasında otokorelasyon olmadığı sonucuna ulaşılmıştır" (Genceli, 1973: 179).

Annelerin demokratik tutum düzeyi ile öfke belirtileri, ciddiye alınmama, haksızlığa uğrama, eleştirilme ve depresyon düzeyleri arasında ilişki bulunmamış olup regresyon analizinde değerlendirmeye alınmamıştır. Ayrıca bulunan bulgulara göre annenin çocuk yetiştirme tutumlarından demokratik tutumunu, annelerin öfke belirtileri, ciddiye alınmama, haksızlığa uğrama, eleştirilme ve depresyon düzeylerinin etkilemediği değerlendirilmiştir.

Annelerin otoriter tutum düzeyi ile ciddiye alınmama, haksızlığa uğrama, eleştirilme ve depresyon düzeyleri arasında ilişki bulunmamış olup regresyon analizinde değerlendirmeye alınmamıştır. Ayrıca bulunan bulgulara göre annenin çocuk yetiştirme tutumlarından otoriter tutumunu, annelerin ciddiye alınmama, haksızlığa uğrama, eleştirilme ve depresyon düzeylerinin etkilemediği değerlendirilmiştir. Annelerin öfke belirtileri düzeyinin otoriter tutum üzerindeki etkisine yönelik lineer regresyon analizi Tablo 9'da sunulmuştur.

Tablo 9: Öfke Belirtilerinin Otoriter Tutum Üzerindeki Etkisine Yönelik Lineer Regresyon Analizi

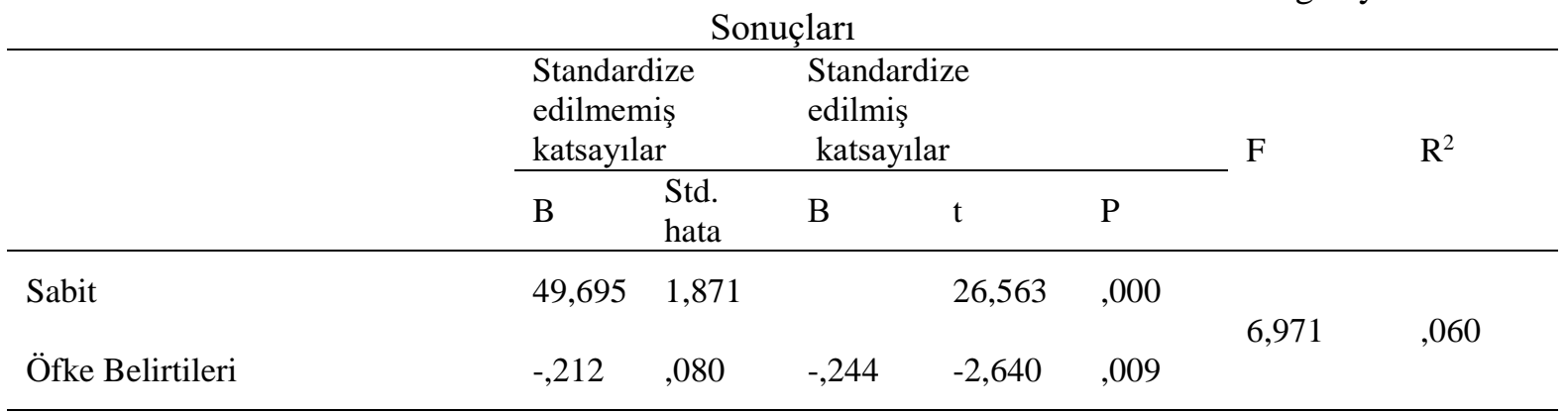

Bağimli Değişken: Otoriter Tutum

$* \mathrm{p}<0.01$

Tablo 9'da görüldüğ̈̈ gibi, öfke belirtileri otoriter tutumu istatistiksel olarak anlamlı ve negatif yönde yordadığ $(\beta=-0.244, \mathrm{t}=-2,640, \mathrm{p}=0.009)$ belirlenmiştir. Bir diğer değişle, çalışma grubunu oluşturan annelerin, öfke belirtileri düzeyleri otoriter tutum düzeylerini negatif yönde etkilemektedir. Ayrıca regresyon eşitliği incelendiğinde ve diğer yordayıcı değişkenler sabit tutulduğunda; annelerin, öfke belirtileri düzeyindeki bir birimlik artış, otoriter tutum düzeyinde 0,212'lik bir azalışa neden olacaktır. Annelerin öfke belirtileri, ciddiye alınmama ve haksızlığa uğrama düzeyinin aşırı koruyucu tutum üzerindeki etkisine yönelik çoklu doğrusal regresyon analizi Tablo 10'da sunulmuştur. 
Tablo 10: Öfke Belirtileri, Ciddiye Alınmama ve Haksızlığa Uğramanın Aşırı Koruyucu Tutum Üzerindeki Etkisine Yönelik Regresyon Analizi Sonuçları

\begin{tabular}{|c|c|c|c|c|c|c|c|}
\hline & \multicolumn{2}{|c|}{$\begin{array}{l}\text { Standardize } \\
\text { edilmemiş } \\
\text { katsayılar }\end{array}$} & \multicolumn{3}{|c|}{$\begin{array}{l}\text { Standardize } \\
\text { edilmiş } \\
\text { katsayılar }\end{array}$} & \multirow[t]{2}{*}{$\mathrm{F}$} & \multirow[t]{2}{*}{$\mathrm{R}^{2}$} \\
\hline & B & $\begin{array}{l}\text { Std. } \\
\text { hata }\end{array}$ & $\beta$ & $\mathrm{t}$ & $\mathrm{P}$ & & \\
\hline Sabit & 24,945 & 6,741 & & 3,700 &, 000 & \multirow{4}{*}{5,797} & \multirow{4}{*}{139} \\
\hline Öfke Belirtileri &, 224 & , 100 & ,200 & 2,230 &, 028 & & \\
\hline Ciddiye Alınmama &,- 120 & ,055 &,- 301 & $-2,207$ & ,029 & & \\
\hline Haksızlığa Uğrama &, 010 & , 120 & ,011 & ,082 & ,935 & & \\
\hline
\end{tabular}

Bağımlı değişken: Aşırı Koruyucu Tutum

$* \mathrm{p}<0.01$

Tablo 10'da görüldügü gibi, annelerin öfke belirtileri, ciddiye alınmama ve haksızlığa uğrama düzeylerinin aşırı koruyucu tutum üzerindeki etkisi birlikte değerlendirildiğinde; annelerin, öfke belirtileri düzeyi aşırı koruyu tutum düzeyini istatistiksel olarak anlamlı ve pozitif $(\beta=0.200$, $\mathrm{t}=2,230, \mathrm{p}=0.028)$ yönde ve ciddiye alınmama düzeyi aşırı koruyucu tutum düzeyini istatistiksel olarak anlamlı ve negatif $(\beta=-0.301, \mathrm{t}=-2,207, \mathrm{p}=0.029)$ yönde yordarken annelerin haksızlığ uğrama düzeyi aşırı koruyucu tutum düzeyini istatistiksel olarak anlamlı yordamamaktadır ( $\mathrm{p}>.05)$. Bir diğer değişle, çalışma grubunu oluşturan annelerin öfke belirtileri, ciddiye alınmama ve haksızlığa uğrama düzeyleri birlikte değerlendirildiğinde; annelerin öfke belirtileri ve ciddiye alınmama düzeyleri aşırı koruyucu tutum üzerinde anlamlı katkı sağlarken haksızlığa uğrama düzeyleri anlamlı katkı sağlamadığı değerlendirilmiştir. Annelerin eleştirilme düzeyinin aşırı koruyucu tutum üzerindeki etkisine yönelik lineer regresyon analizi Tablo 11'de sunulmuştur.

Tablo 11: Eleştirilmenin İzin Verici Tutum Üzerindeki Etkisine Yönelik Lineer Regresyon Analizi Sonuçları

\begin{tabular}{|c|c|c|c|c|c|c|c|}
\hline & \multicolumn{2}{|c|}{$\begin{array}{l}\text { Standardize } \\
\text { edilmemiş } \\
\text { katsayılar }\end{array}$} & \multicolumn{3}{|c|}{$\begin{array}{l}\text { Standardize } \\
\text { edilmiş } \\
\text { katsayilar }\end{array}$} & \multirow[t]{2}{*}{$\mathrm{F}$} & \multirow[t]{2}{*}{$\mathrm{R}^{2}$} \\
\hline & B & $\begin{array}{l}\text { Std. } \\
\text { hata }\end{array}$ & $\beta$ & $\mathrm{T}$ & $\mathrm{p}$ & & \\
\hline Sabit & 27,330 & 2,030 & & 13,460 & ,000 & \multirow{2}{*}{7,758} & \multirow{2}{*}{,066 } \\
\hline Eleștirilme &, 312 &, 112 & 257 & 2,785 & ,006 & & \\
\hline
\end{tabular}

Bağimli Değişken: İzin Verici Tutum $* \mathrm{p}<0.01$

Tablo 11'de görüldüğü gibi, çalışma grubunu oluşturan annelerin, eleştirilme düzeyleri izin verici tutum düzeylerini pozitif yönde etkilemektedir. Ayrıca regresyon eşitliği incelendiğinde ve diğer yordayıcı değişkenler sabit tutulduğunda; annelerin, eleştirilme düzeyindeki bir birimlik artış, izin verici tutum düzeyinde 0,312 'lik bir artışa neden olacaktır.

\section{Sonuç, Tartışma ve Öneriler}

$\mathrm{Bu}$ çalışmanın amacı 2-6 yaş arası çocuğu olan annelerin öfke düzeyi ile çocuk yetiştirme tutumu arasındaki ilişkinin incelenmesidir. Bu bağlamda yapılan araştırma sonucunda çalışmaya katılan annelerin demokratik tutum düzeyi ile öfke belirtileri, ciddiye alınmama, haksızlığa uğrama, 
eleştirilme ve depresyon düzeyleri arasında anlamlı ilişki bulunmamıştır. Ayrıca bulunan bulgulara göre annenin çocuk yetiştirme tutumlarından demokratik tutumunu, annelerin öfke belirtileri, ciddiye alınmama, haksızlığa uğrama, eleştirilme ve depresyon düzeylerinin etkilemediği tespit edilmiştir. Buna ek olarak otoriter tutum düzeyi ile ciddiye alınmama, haksızlığa uğrama, eleştirilme ve depresyon düzeyleri arasında ilişki bulunmamış olup, çocuk yetiştirme tutumlarından otoriter tutumunu, annelerin ciddiye alınmama, haksızlığa uğrama, eleştirilme ve depresyon düzeylerinin etkilemediği değerlendirilmiştir. Park vd. (2016) ebeveyn tutumları üzerine yaptığ1 çalışmada ebeveyn reddetme davranışının çocukların özgüvenini düşürdüğünü belirtirken kız çocuklarda depresyonla ilişkili bulduğu bu davranışın erkek çocuklarda depresyona neden olmadığını bulmuştur. Mennen ve Trickett (2011) çocuklarına kötü davranan annelerin anksiyete ve depresyon seviyelerinin diğer annelere göre bariz şekilde yüksek olduğunu belirtmiştir. Boggs (2018) otoriter, otoriteci ve izin verici ebeveynlik stillerinin çocukların mental sağlığına ve iyi olma hallerini incelemiş ve ebeveynlik stillerinin bu değişkenlere anlamlı etkilerinin olmadığını ancak otoriter ebeveynliğin etkili olmaya en yakın olarak görüldüğünü belirtmiştir. Bu çerçevede sonuçlarımızın literatürde bazı çalışmalarca desteklenip bazılarınca desteklenmediği görülmektedir. Yapılan araştırma sonucunda annelerin aşırı koruyucu tutum düzeyi ile eleştirilme ve depresyon düzeyleri arasında ilişki bulunmamış, çocuk yetiştirme tutumlarından aşırı koruyucu tutumunu, annelerin eleştirilme ve depresyon düzeylerinin etkilemediği gözlemlenmiştir. Buna ek olarak annelerin öfke belirtileri, ciddiye alınmama ve haksızlığa uğrama düzeyleri birlikte değerlendirildiğinde; annelerin öfke belirtileri ve ciddiye alınmama düzeyleri aşırı koruyucu tutum üzerinde anlamlı katkı sağlarken haksızlığa uğrama düzeyleri anlamlı katkı sağlamadığı değerlendirilmiştir. İzin verici tutum düzeyi ile öfke belirtileri, ciddiye alınmama, haksızlığa uğrama ve depresyon düzeyleri arasında ilişki bulunmamış olup regresyon analizinde değerlendirmeye alınmamıştır. Ayrıca bulgulara göre annenin çocuk yetiştirme tutumlarından izin verici tutumunu, annelerin öfke belirtileri, ciddiye alınmama, haksızlığa uğrama ve depresyon düzeylerinin etkilemediği değerlendirilmiştir. Vafaeenejad vd. (2019) Ebeveynlerde depresyon anksiyete, düşük özyeterlilik ve stresin çocuğa kötü davranmayı arttırdığını belirtmiştir. Hedstrom (2016) otoriter ebeveynliğin depresyon, yalnızlık ve düşük öz sayg1 ile bağlantılı olduğunu belirtmektedir. Bu konuda genellikle çocukları psikolojik durumunun incelenip ebeveynlere bu konuda pek değinilmediği görülmektedir. Ancak ebeveynin psikolojik sorunlarının her zaman için çocuğa kötü davranma ile ilgili olduğu görülmektedir. İzin verici ve aşırı koruyucu tutumun doğrudan kötü davranma olarak nitelenemeyeceğinden dolayı bulgularımızda bir ilişki bulmamamız literatürle örtüşür.

Anne ve çocuklarının demografik profili ile araştırma değişkenleri arasındaki ilişkiler irdelendiğinde; 24-36 yaş arası ya da 37 yaş ve üzeri anne olmak; araştırma grubunu oluşturan annelerin demokratik tutum düzeylerini etkilerken annelerin öfke belirtileri, ciddiye alınmama, haksızlığa uğrama, eleştirilme, otoriter tutum, aşırı koruyucu tutum, izin verici tutum ve depresyon düzeylerini etkilemediği sonunca varılmıştır. Buna ek olarak 1 çocuğunun ya da 2 ve üzeri çocuğunun olması; araştırma grubunu oluşturan annelerin demokratik tutum ve otoriter tutum düzeylerini etkilerken annelerin öfke belirtileri, ciddiye alınmama, haksızlığa uğrama, eleştirilme, aşırı koruyucu tutum, izin verici tutum ve depresyon düzeylerini etkilememektedir. Ayrıca 2-6 yaş arası çocuklarının kadın ya da erkek olması; araştırma grubunu oluşturan annelerin öfke belirtileri, ciddiye alınmama, haksızlığa uğrama, eleştirilme, demokratik tutum, otoriter tutum, aşırı koruyucu tutum, izin verici tutum ve depresyon düzeylerini etkilemediği görülmüştür. Vyas ve Bano (2016) ebeveynlerin kız çocuklara erkek çocuklara göre daha fazla otoriter ebeveynlik uyguladıklarını bulmuştur. Bu bizim bulgularımızla çelişir. Ancak Gilli (2016) tam tersi bir sonuç bulmuştur. $\mathrm{Bu}$ da verilerimizle çelişir zira bizim çalışmamızda değişiklik gözlemlenmemiştir. Kolburan vd (2012) erkeklerin annelerini daha otoriter ve koruyucu bulduklarını, kızların ise babalarını daha demokratik ve koruyucu bulduklarını belirtmektedir. Alidosti vd (2016) 1'den fazla çocuk olmasının izin verici ebeveynliği azalttı̆̆ını, otoriterliği ise arttırdığını göstermiştir. Bu da 
verilerimizle örtüşür. $\mathrm{Bu}$ durumun sebebi olarak çocuk sayısının artmasının aile yapısını değiştirdiğini ayrıca tecrübe kazanan ebeveynlerin ebeveynlik stillerini daha iyiye gidecek bir şekilde değiştirdiğini söyleyebiliriz.

Annelerin 2-6 yaş arası çocuklarının 2-4 yaş arası ya da 5-6 yaş arası olması; araştırma grubunu oluşturan annelerin öfke belirtileri, ciddiye alınmama, haksızlığa uğrama, eleştirilme, demokratik tutum, otoriter tutum, aşırı koruyucu tutum, izin verici tutum ve depresyon düzeylerini etkilememektedir. Ayrıca annelerin eğitimi; araştırma grubunu oluşturan annelerin haksızlığa uğrama, demokratik tutum ve otoriter tutum düzeylerini etkilerken annelerin öfke belirtileri, ciddiye alınmama, eleştirilme, aşırı koruyucu tutum, izin verici tutum ve depresyon düzeylerini etkilemediği sonucuna varılmıştır. Annelerin çalışması ya da çalışmaması, araştırma grubunu oluşturan annelerin demokratik tutum düzeylerini etkilerken annelerin öfke belirtileri, ciddiye alınmama, haksızlığa uğrama, eleştirilme, otoriter tutum, aşırı koruyucu tutum, izin verici tutum ve depresyon düzeylerini etkilemediği; hanesine gire gelirin orta/düşük ya da yüksek olması; araştırma grubunu oluşturan annelerin öfke belirtileri ve otoriter tutum düzeylerini etkilerken annelerin ciddiye alınmama, haksızlığa uğrama, eleştirilme, demokratik tutum ve aşırı koruyucu tutum, izin verici tutum ve depresyon düzeylerini etkilemediği sonucuna varılmıştır. Alidosti vd (2016) ev hanımı olan annelerin otoriter stillerini değiştirdiğini belirtmiştir. Bu durum izin verici ebeveynliği ise kısmen etkilemektedir. Alabay (2017) çalışmayan ebeveynlerin daha koruyucu olduklarını belirtmiştir. Şanlı ve Öztürk'e göre (2015) göre eğitim ve gelir düzeyinin artması ve çocuk sayısının azalması sonucunda otoriter tutum azalır, demokratik ve izin verici tutum artmaktadır. Tutumun bu faktörlerden etkilenmediği çalışmamızda da görülen bir durumdur.

Roopnarine, Jin ve Krishnakumar (2014) Guyanalı anneler, çocuk bakım rutinleri ve bu rutinlerin çocuklar üzerindeki belirtilerini araştırmışlardır. Yaptıkları çalışmanın sonucunda annelerin çocuklara uyguladıklar öfke yansitan fiziksel temaslar ile koruyucu tutumları arasında pozitif yönlü korelasyon olduğunu tespit etmişlerdir. Burada sonuçları paylaşılan araştırma ile de annelerin öfke belirtileri düzeyi ile koruyucu tutum arasında pozitif yönlü ilişki olduğu ortaya konmuştur. Araştırmalar bu bakımdan birbirini destekler niteliktedir. Her ne kadar yürütülen araştırma ile yalnızca öfke belirti düzeyi konu alınmışsa da, sonuç tutumun temsil ettiği değerler benzerdir. İki çalışmanın farklı coğrafyada benzer sonuçlar vermesi de dikkate değer bir durumdur.

Malete (2007) araştırmasında ergenlerin sergilediği anti sosyal davranışlar ve bunların ailevi bağlantılarını incelemiştir. Bu amaçla 12-20 yaş arasındaki 1.478 genç üzerinde yapılan çalışma sonucunda, ergenlerin şiddet içeren ve anti sosyal davranışları ile ailelerin düşük kontrol düzeyi ile yetersiz ebeveyn çocuk ilişkileri arasında anlamlı bağlantılar tespit edilmiştir. $\mathrm{Bu}$ araştırma sonucunda ortaya konan artan öfke belirtisi düzeyi ile azalan otorite tutum düzeyi ile Malete'nin (2007) araştırma sonuçları birlikte incelendiğinde. Öfke belirtisi düzeyindeki artışın ergenlerin sosyal tutumları üzerinde negatif etkileri olduğu çıkarımı yapılabilir. Kurulan bağlantının yeterliliği araştırmaya muhtaç olmakla birlikte, öfke belirti düzey artışının negatif etkiler yine bu çalışma ile ortaya konmaktadır. Çalışmamızda annelerin ciddiye alınmama, haksızlığa uğrama ve eleştirilme seviyelerinin ebeveynlik tutumları bağlamında incelenmesi literatür için yeni bir olgudur. Bu çalışma literatüre yeni bir bakış açısı getirerek olumsuz ebeveyn tutumlarının sebeplerinin daha iyi anlaşılması açısından yararlı olacaktır.

Daha önce aile yapısı ile ruhsal durumunu birlikte incelemiş olan çalışmalardan birini yapmış olan Çuhadaroğlu-Çetin ve diğerleri (2004) sundukları raporda ergenlerin ruhsal durumlarını ile aile yapılarını birlikte incelemiştir. Raporda sorun çözme, iletişim, sosyal roller, duygusal tepki ve yeterli sosyal beceri düzeyine sahip olmayan çocukların, ebeveynlerinde de yeterli sosyal becerilerinin olmadığı izlenmiştir. Bu araştırma sonucunda ortaya konan artan öfke belirtisi düzeyi ile azalan otorite tutum düzeyi ve ciddiye alınmama düzeyi ilişkisini, ÇuhadaroğluÇetin ve diğerlerinin (2004) rapor sonucu ile ilişkilendirmek gerekirse, öfke belirtisi düzeyi, sosyal beceri seviyesi ile ilişkilendirildiğinde, yetiştirilen çocuğun maruz kaldığı yüksek öfke belirtisi 
düzeyinin, ergen olduğunda sergileyeceği düşük sosyal becerilere sebep olacağı söylenebilir. İki araştırma arasındaki bu ilişkilendirmenin derinlemesine incelenmesi için yeni araştırma önerileri getirilebilir.

Morris ve diğerlerinin (2011) yaptıkları araştırma ile anne ve çocuk ilişkisinde, bir duygusal kontrol strateji metodu önermiş ve bu uygulama ile bireyler üzerinde gözlemlenen ve beyan edilen duygusal durumları raporlamıştır. Araştırma sonucunda önerilen stratejinin uygulandığı durumlarda çocuklar üzerinde gözlemlenen ve beyan edilen üzgünlük durumları üzerinde olumlu be ters yönlü bir bağlantı olduğunu tespit etmiştir. Burada sonuçları paylaşılan araştırma sonuçları ile Morris ve diğerlerinin (2011) yaptıkları araştırmanın sonucu birlikte ele alındığında, öfke belirtisi düzeyinin çocukların üzerinde gözlemlenen üzgünlük seviyesi üzerinde doğrusal bir ilişki olduğu düşünülebilir. Araştırmada gözlemlenen demografik grupların da etkin rol oynayabileceği düşünüldügünde, araştırmalar arasındaki ilişkinin açıklanması adına, yeni araştırma önerileri de getirilebilir.

Kabasakal (2013) yaptığı çalışma ile anne eğitim programlarının işlevselliğini incelemiştir. Araştırma sonucundan şiddet içeren davranış sergileyen çocuklu ailelerin işlevsellik düzeyleri yedi temel işlev açısından sağliklı bulunmamıştır, bu işlevler; problem çözme, iletişim, temel roller, duygusal tepki yeteneği, gerekli kaygı seviyesi, davranış kontrolü ve genel işlevler. Kabasakal'ın (2013) araştırması ile burada paylaşılan ciddiye alınma, otorite sağlama ve öfke seviyesi belirtisi düzeyi ilişkisi göz önüne alındığında, araştırma sonuçlarının birbirini desteklediği, ciddiye alınma ve otorite sağlama seviyesi ile çocukların işlevsel becerileri üzerindeki etkisi arasında bağlantı olduğu söylenebilir. Kısacası öfke, ciddiye alınmama, haksızlığa uğrama, eleştirilme, üzgünlük gibi psikolojik durumlar ebeveynlik tutumunu etkiledikleri gibi ebeveynlik tutumu da gerek çocuklarda gerek ebeveynleri bunları etkilemektedir. Ortadaki bu çift yönlü ilişki bu konunun önemini ortaya koymakta ve bu kavramlar arasındaki ilişkilerin daha fazla araştırma için ideal bir konu olmasını sağlamaktadır.

$\mathrm{Bu}$ araştırmadan elde edilen bulgular çerçevesinde uygulayıcılara yönelik öneriler şu şekilde suralanabilir;

- Ebeveynlere çocuklarına ve birbirlerine nasıl davranmaları gerektiği, çocuk için neyin iyi neyin kötü olduğuna basmakalıp fikirler ile karar verilmemesi gerektiği gibi temel konularda 'ebeveynlik eğitimleri verilmesi' gerektiği,

- Ebeveynlerin demokratik tutumları ile otoriter tutumları arasındaki farkın çocuklar üzerinde bıraktıkları etkileri hakkında bilgilendirmeler yapılması gerektiği,

- Çocukların bu yaş aralığında duygusal ve sosyal olarak geçirdikleri değişimler konusunda ebeveynlere ilgili eğitimler verilmesi gerektiği.

\section{Kaynakça}

Alabay, E. (2017). Okul öncesi dönem çocuğu olan ebeveynlerin ebeveynlik tutumlarının incelenmesi. Erken Çocukluk Çalışmaları Dergisi, 1 (2), 156-174. http://dx.doi.org/10.24130/eccdjecs.196720171234

Alidosti, M., Dehghani, S. L., Heydarabadi, A. B., \& Tavassoli, E. (2016). Comparison of Parenting Style in Single Child and Multiple Children Families. Iranian Journal of Health Sciences, 4 (2), 49-54.

Aydın, B., \& Öztütüncü, F. (2001). Examination of adolescents' negative thoughts. Adolescence (36), 77-83. http://dx.doi.org/10.18869/acadpub.jhs.4.2.49

Balat, G. U. (2010). İlköğretime başlayan çocukların anne babalarının çocuk yetiştirme tutumlarının okul öncesi eğitimden yararlanma düzeylerine göre incelenmesi. Eğitim ve Bilim Dergisi, 32(143), 349-402. 
Balkaya, F., \& Şahin, N. H. (2003). Çok Boyutlu Öfke Ölçeği. Türk Psikiyatri Dergisi, 14 (3), 192-202.

Baltaş, A., \& Baltaş, Z. (2008). Stres ve Başa Çıkma Yolları (24. b.). Remzi Kitabevi.

Beck, A. T., Ward, C., \& Mendelson, M. (1961). Beck depression inventory (BDI). Arch Gen Psychiatry, 4 (6), 561-571. http://dx.doi.org/10.1093/occmed/kqv087

Bilge, F., \& Sayın, S. (1994). Uyum Düzeyleri Farklı Olan Üniversite Öğrencilerinin Öfke. II:Ulusal Psikolojik Danışma ve Rehberlik Kongresi Bilimsel Çalışmaları (s. 111-120). Psikolojik Danışma ve Rehberlik Derneği Yayını.

Boggs, J. (2018). Parenting Styles and Mental Health: Measuring the relationship between Authoritative, Authoritarian, and Permissive parenting styles and their effects on Mental Health. USFSP , 1-38.

Çuhadaroğlu-Çetin, F., Canat, S., Kılıç, E., Şenol, S., Rugancı, N., \& Öncü, B. (2004). Ergen ve ruhsal sorunlar durum saptama çalışması [State determination study regarding teenagers and mental problems]. Türkiye Bilimler Akademisi Raporları.

Çelik, H. (2006). Üniversite birinci sınıf ögrrencilerinin saldırganlık tepkileri, bağlanma tarzları ve kişiler arası şemaların incelenmesi [Yayınlanmamış yüksek lisans tezi]. Marmara Üniversitesi Sosyal Bilimler Enstitüsü.

Çıkrıkçı, S. (1999). Ankara il merkezinde resmi banka anaokullarına devam eden 5-6 yaş çocuklarının okul olgunluğu ile aile tutumu arasindaki ilişkinin incelenmesi [Yayınlanmamış Yüksek Lisans Tezi].Gazi Üniversitesi Sosyal Bilimler Enstitüsü.

Demir, E. K., \& Şendil, G. (2008). Ebeveyn Tutum Ölçeği (ETÖ). Türk Psikoloji Yazıları Dergisi, 11 (21), 15-25. https://doi.org/10.9779/pauefd.439949

Doğan, N., \& Başokçu, T. O. (2010). İstatistik Tutum Ölçeği İçin Uygulanan Faktör Analizi ve Aşamalı Kümeleme Analizi Sonuçlarının Karşılaştırılması. Eğitimde ve Psikolojide Ölçme ve Değerlendirme Dergisi, 1 (2), 65.

Eser, D. T., \& Üstün, B. (2011). Psikiyatrik Bozukluğu Olan Ergen ve Ebeveynlerinin Öfke İfade Biçimleri Arasındaki İlişkinin İncelenmesi. Psikiyatri Hemşireliği Dergisi, 2 (3), 111-116.

Genceli, M. (1973). İki Değişkenli Doğrusal Regresyonda Zaman Faktörü. İstanbul Üniversitesi İktisat Fakültesi Mecmuast, 33 (1), 179.

George, D., \& Mallery, M. (2010). SPSS for Windows Step by Step: A Simple Guide and Reference. Pearson.

Gilli, S. (2016). Gender Bias in Parenting Styles and its Contribution to Gender Differences in Empathy. Department of Psychology, University of Cape Town.

Gülay, H, \& Önder, A. (2011). Annelerin tutumlarına göre 5-6 yaş çocuklarının sosyalduygusal uyum düzeyleri. Celal Bayar Üniversitesi Eğitim Fakültesi Dergisi, 1(1), 89-105.

Hedstrom, E. (2016). Parenting Style as a Predictor of Internal and External Behavioural Symptoms in Children: the child's perspective. HKR , 1-24.

Kabasakal, Z. (2013). The Effects of Mother Education Programs on the Functionality, Anger Management and Conflict Solution Levels of Families. Eurasian Journal of Educational Research (52), 1-20.

Karataş, Z., \& Çelikkaleli, Ö. (2018). Beliren Yetişkinlikte İntihar Olasılığı: Stresle Başetme, Öfke ve Cinsiyet Açısından Bir İnceleme. Mersin Üniversitesi Eğitim Fakültesi Dergisi, 14 (1), 450-462. http://dx.doi.org/10.17860/mersinefd.402052 
Kolburan, G., Comert, I. T., Narter, M., \& Isozen, H. (2012). Parental Attitude Perception in Adolescents by Gender. Procedia - Social and Behavioral Sciences (47), 1299-1304. https://doi.org/10.1016/j.sbspro.2012.06.815

Maccoby, E. E. (2002). Gender and group process: A developmental perspective. Current directions in psychological science, 11(2), 54-58.

Malete, L. (2007). Aggressive and antisocial behaviours among secondary school students in Botswana: The influence of family and school based factors. School Psychology International, 28 (1), 90-109. https://doi.org/10.1177/0143034307075683

Mazlum, M. M., \& Mazlum, A. A. (2017). Sosyal Bilimlerde Araştırma Yönteminin Belirlenmesi. Route Educational and Social Science Journal, 4 (4), 1-21.

Mennen, F., \& Trickett, P. (2011). Parenting Attitudes, Family Environments, Depression, and Anxiety in Caregivers of Maltreated Children. National Council on Family Relations, 60 (3), 259-271. https://doi.org/10.1111/j.1741-3729.2011.00646.x

Morris, A. S., Silk, J. S., Morris, M. D., Steinberg, L., Aucoin, K. J., \& Keyes, A. W. (2011). The influence of mother-child emotion regulation strategies on children's expression of anger and sadness. Developmental psychology, 47 (1), 213. https://doi.org/10.1037/a0021021

Özer, Z. (1997). Duygu dünyasının bam teli öfke. Bilim ve Teknik Dergisi (354), 80-84.

Özyürek, A., Çetin, A., Yıldırım, R., Evirgen, N., \& Ergün, Ş. (2016). Farklı Kültürlerde Aile Çocuk Etkileşimlerinin Öğretmen Bakış Açısına Göre İncelenmesi. Uluslararası Sosyal Araştırmalar Dergisi, 9 (43), 1477-1484. https://doi.org/10.17719/jisr.20164317718

Park, S., Kim, B., \& Park, M. (2016). The relationship between parenting attitudes, negative cognition, and the depressive symptoms according to gender in Korean adolescents. International Journal of Mental Health Systems, 10 (35), 1-8. https://doi.org/10.1186/s13033-0160069-3

Prinzie, P., Stams, G. J., Dekovic, M., Reijntjes, A. H., \& Belsky, J. (2009). The relations between parents' Big Five personality factors and parenting: A meta-analytic review. Journal of Personality and Social Psychology, 97 (2), 351-362. https://doi.org/10.1037/a0015823

Roopnarine, J. L., Jin, B., \& Krishnakumar, A. (2014). Do Guyanese mothers' levels of warmth moderate the association between harshness and justness of physical punishment and preschoolers' prosocial behaviours and anger? International Journal of Psychology, 49 (4), 271279. https://doi.org/10.1002/ijop.12029

Safran, J. D. (1990). Towards a Refinement of Cognitive Therapy in Light of Interpersonal Theory: I. Theory. Clinical Psychology Review (10), 87-105. https://doi.org/10.1016/02727358(90)90108-M

Seçer, İ. (2015). Spss ve Lisrel ile Pratik Veri Analizi. Anı Yayınc111k. Akademi.

Senemoğlu, N. (2009). Gelişim Öğrenme ve Öğretim, Kuramdan Uygulamaya. Pegem

Spielberger, C. (1995). Measuring the Experience, Expression, and Control of Anger. Issues in Comprehensive Pediatric Nursing (3), 207-232. https://doi.org/10.3109/01460869509087271

Şanlı, D., \& Öztürk, C. (2015). Anne Babaların Çocuk Yetiştirme Tutumları ve Tutumlar Üzerine Kültürün Etkisi. DEUHFED, 8 (4), 240-246.

Şendil, G. (2003). Çocuk, Ergen ve Anne Baba. Çantay Yayınları. 
Tatlılığlu, K., \& Karaca, M. (2013). Öfke Olgusu Hakkında Sosyal Psikolojik Bir Değerlendirme. The Journal of Academic Social Science Studies, 6 (6), 1101-1123. http://dx.doi.org/10.9761/JASSS1691

Vafaeenejad, Z., Elyasi, F., Moosazadeh, M., \& Shahhosseini, Z. (2019). Psychological factors contributing to parenting styles: A systematic review . F1000 Research , 1-19. http://dx.doi.org/10.12688/f1000research.14978.2

Vyas, K., \& Bano, S. (2016). Child's Gender and Parenting Styles. Delhi Psychiatry Journal, 19 (2), 289-293.

Yaşar, F. (2009). İlköğretime devam eden öğrencilerin anne-çocuk ilişkisini kabul ve reddedici algllama düzeyinin annenin evlilik doyumu ve evlilik uyumu düzeyiyle ilişkisi[Yayınlanmamış Yüksek Lisans Tezi]. Çukurova Üniversitesi Sosyal Bilimler Enstitüsü.

Yavuzer, H. (2014). Çocuğu tanımak ve anlamak. Remzi Kitabevi. 